\title{
Last Writing: Script Obsolescence in Egypt, Mesopotamia, and Mesoamerica
}

\author{
STEPHEN HOUSTON
}

\author{
Brigham Young University
}

\section{JOHN BAINES}

University of Oxford

\author{
JERROLD COOPER
}

The Johns Hopkins University

\section{INTRODUCTION: SETTING THE QUESTIONS}

By any measure, the creation and development of writing was a cybernetic advance with far-reaching consequences. It allowed writers to communicate with readers who were distant in time and space, extended the storage capacity of human knowledge, including information that ranged from mundane accounting to sacred narrative, bridged visual and auditory worlds by linking icons with meaningful sound, and offered an enduring means of displaying and manipulating assertions about a wide variety of matters. ${ }^{1}$ In part, the first writing at-

Acknowledgments: John Baines wishes to acknowledge the help and expert criticism of John Tait and John Bennet, the advice of William Peck about a coffin in the Detroit Institute of Arts, and of Kim Ryholt about the Tebtunis onomasticon. Stephen Houston thanks Michael Coe, Robert Sharer, Karl Taube, Bruce Trigger, and David Webster for advice and close reading. John Robertson was particularly helpful with suggestions; Matthew Restall reminded us that Gaspar Antonio Chi came under Franciscan care at a tender age. Nicholas Dunning provided photographs from Yaxhom, and Scott Ure did the maps. Two reviewers, one being John Monaghan and the other anonymous, did a superb and sympathetic job of evaluating the manuscript.

1 Broader definitions of writing that embrace purely semantic devices (semasiography, Sampson 1985:29) relate to ancient systems of communication, especially "Mexican pictography" (Boone 2000:29), but depart from the linguistic underpinnings that characterize the writing systems reviewed here. Semasiographic definitions are not very helpful in understanding heavily phonic systems. Their limited applicability to writing systems of the world identifies a typological weakness; even the Mexican examples are inconclusive, since these texts bundle genuine lexical items with supporting graphic devices. An alternative view is that the mixed Mexican pictography contains writing, yet supplements it with effective pictorial clues. From this comes a narrative that is translatable, with some controlled liberties, into language. Equating this distinctive package of features with the preponderantly phonic nature of Egyptian, cuneiform, or Mayan glyphs blurs dis- 
tracts attention because it contributes to a teleological narrative of progress (Trigger 1998: 42). The invention of writing is thought, with good justification, to undergird and enable present-day society. In its more developed forms, it is indispensable to bureaucracy, propaganda, and administration.

However, the comparative literature on writing systems takes little notice of unraveling script traditions, the phases of terminal use when forms of writing passed into extinction. Today, Egyptian hieroglyphic writing, Mesopotamian cuneiform, and Mayan glyphs, the scripts under review here, persist only in the sense that modern specialists teach them in academic settings or artisans incorporate them into trinkets and tourist art. Ancient scribes were authentic participants in their script communities (see note 2 for terms). Present-day specialists, particularly in scripts undergoing decipherment, have no such grounding.

Just as the first writing needs study (Senner 1989; Houston 2003a), so does the last writing. Beginnings and origins, whether of writing or states, find their antithesis in endings and collapse (Eisenstadt 1988:237), although the obsolescence of scripts tends to be far more absolute than the decay, however rapid, of complex societies (Tainter 1988:4; Yoffee and Cowgill 1988). Historical links mean that looking at origins and at collapse leads to reciprocal insights. Nonetheless, comparative research on recondite matters like extinct writing runs the risk of identifying broad patterns that in fact arise, not from trajectories common to humanity, but from deficient understanding of individual traditions. No one person can command all relevant information. Interpretations change rapidly, and publication typically lags behind the outer envelope of knowledge, especially for the evolving understandings of New World writing. It is better to arrange a dialogue between specialists of distinct traditions (here the major, extinct scripts of Egyptian, cuneiform, and Mayan), concerned to chart the obsolescence of those traditions in a controlled comparison. Generalization should be related to a consideration of difference. ${ }^{2}$ Both in order to pro-

tinctions. A broad definition of writing does not elucidate these scripts, although it is useful for understanding the relation of texts and accompanying images (Baines 1989; Taube 2000).

2 Some definitions are in order and some terms need to be introduced because current terminology does not describe necessary concepts. "Writing," used interchangeably with "script," adjectivally as "scriptural," is the graphic encoding of lexemes and, ultimately, of syntax. "Writing system" emphasizes the codified, systematic nature of a particular script. Writing can go beyond the work of language by use of iconicity, such as the Mayan use of a snake head to specify that meaning over other, possible homophones, or by disambiguations that reject one meaning in favor of another (English [be] vs. [bee]). Script is also a communicative practice that intermeshes with orality. Writing under-represents language to varying degrees. The earliest writing augments the capacity of memory by depending, paradoxically, on oral comment and acts of memory. This is also true of some of the latest texts from all the traditions we study. A "script community" is a socially constituted group that uses and disseminates writing across generations through apprenticeship and other modes of training. A "terminal script community" is the last to make effective use of a particular writing system. The end of writing is "script obsolescence" or "terminal use." As with "language death," "script death" is a metaphor that injects both the vivid qualities and the inherent flaws of biological metaphor: scripts have no last breath, rictus, or flatline. They "expire" because social and cultural practices no longer maintain them across generations. They have "terminal writers" or 
vide a reasonable basis for comparison and because we are asking questions not addressed in the existing literature, we include relatively full treatments of the three individual cases.

Some concepts of script obsolescence (see note 2) are derived by analogy from the literature on language "death" (Dorian 1981; 1989; Campbell and Muntzel 1989). Nonetheless, a tension comes from applying the terminology of one to the other; any discussion of similarity and difference is necessarily complex. It is possible to tally both why script obsolescence is not like language death and why the two share a number of features.

\section{LANGUAGE DEATH AND SCRIPT OBSOLESCENCE: DIFFERENCES}

Writing is not language. It is a graphic conveyance of meaning and sound, and has a communicative and existential role, being artifact as much as message. Certain monastic orders or sects may suppress speech-thus the early, probably incorrect, explanation that Ogam in Celtic Britain and Ireland emerged from Druidic sign language (Sims-Williams 1993:134-35). The key difference is that language resides, according to recent reports, in the human genome, an assertion that cannot be made for writing. ${ }^{3}$ People can learn a new language but, unless in some way impaired, they do not stop talking. This ability is essential to social life; its use is non-optional. For this reason, the use of "death" in describing the extinction of script is evocative but misleading. We prefer "obsolescence" for the reason that it means simply to "go out of use" and does not employ a biological metaphor.

In contrast to language, writing can disappear, as happened in the case of Indus civilization, to be replaced by scriptural silence for over 1650 years (1900250 b.c.; Parpola 1994:24, 56). Similarly, in parts of later, post-Indus India, scripts were closely linked to the creation of sprawling polities, Brāhmī with the Mauryan empire (ca. third century B.C.), and, in disappearance, to their dissolution, as with Kharosthī and the Kusāna empire (ca. third century A.D.; Salomon 1998:12, 47; but see Coningham et al. 1996, for a revised Brāhmī chronology prompted by finds in Sri Lanka). Moreover, children learn language with aplomb, whereas writing presupposes more formal instruction, especially rote memorization and mechanical repetition. In pre-modern societies, script leans strongly to restricted use (primarily a matter of literacy) and application

\footnotetext{
"readers," who may or may not belong to the same category, a reader being potentially more passive and less skilled than a writer. "Grapholect" parallels "dialect," pointing to a subset of a writing system that corresponds to the social and regional background of the writer. As Maya decipherment advances, it considers increasingly the grapholects of certain kingdoms or regions and the script communities that created such variants. "Biscript" refers to a text in two different writing systems. "Biliteracy" and "triliteracy" label the concurrent use of two or three scripts. A "dominant script" carries superordinate prestige and benefits from social, religious, or political, factors that comprehensively favor its use. The "abandoned script" is left behind for a "target script."

${ }^{3}$ See Pinker (2001). To be sure, symboling and image-making may represent an exclusive attribute of anatomically modern humans (Mithen 1994:36).
} 
(a question of genre and context, e.g., Goody 1968; Baines 1983; Harris 1989; Houston 1994a).

Many languages have disappeared, notably in the last 100 years, and many more are in grave danger of doing so (Crystal 2000:14-15; Sasse 1992:7). Script obsolescence is far rarer, primarily because languages vastly outnumber writing systems. Today, some 6,000 or more languages exist (Dixon 1997:143), whereas not many more than 100 scripts are attested (depending on how they are lumped and divided: Gaur 1992:216-26; Campbell 1997:vii). Nonetheless, it is possible that scripts were invented with some frequency, but without the means to transmit them down generations or develop them from temporary expedients into sustained traditions (John Monaghan, personal communication, 1999). David Crystal (2000:15) asserts that if it is to survive in the modern world a spoken language requires in excess of 20,000 speakers. In cases such as isolated languages in insular settings, this number is clearly too large.

On present evidence, writing needs far fewer people. In theory, script requires but one reader. In practice, its survival presupposes a social investment and relatively broad use. Numbers are hard to pin down, and, given the social context emphasized here, may not be instructive for our comparative purposes. At one extreme Rongorongo script on Rapa Nui (Easter Island) survived for many generations with a total sustaining population of fewer than 10,000 and an unknown, probably altogether smaller number of readers and writers (Kirch 2000:272; dating remains controversial-some opt for a brief span of use, e.g., Fischer 1997:6-7). However, the island's extreme isolation and self-sufficiency make it exceptional. Until the arrival of Spanish, it had no "target" language or script to adopt. In Älvdalen, Sweden, where over 90 percent of late early-modern runes are found, albeit often mixed with Latin letters, there were only 1000 to 3000 people at any given time (Gustavson and Hallonquist 1994:157). Another example is the highly restricted use of Silas John's shamanistic writing system among the Western Apache (Basso and Anderson 1975:9-10); but the long-term viability of that script is doubtful, since shamanic scripts, such as Nakhi (Naxi) in China, flutter into extinction along with the rites that motivated them (Jackson 1979:74). ${ }^{4}$ It is important not to fixate on numbers but to observe that script persists when circumstances promote survival. The number of writers and readers required is evidently smaller than that needed for robust language maintenance.

\section{LANGUAGE DEATH AND SCRIPT OBSOLESCENCE: SIMILARITIES}

In other respects, however, language death is similar to script obsolescence. Languages disappear because they are stigmatized or elicit negative prestige

4 Na-khi religion is thought now to have just two fully trained dto-mba (dongba) or ritual specialists who can use Na-khi pictography (Eckholm 2000). Even at their most active, these specialists served only as part-time scribes, spending much of their time farming. 
(Dorian 1989:2). So too for scripts. To paraphrase Grillo, "a subordinate script is a despised script" (Grillo 1989:173-74; Dorian 1998:7), although the real question is what caused those stigmata to develop. A terminal script community can encompass a wide range of expertise, much like that of a disappearing language. There may be strong writers and readers, imperfect or semi-literates, and, in extremis, "rememberers" who may recall some written signs or the fact that earlier generations employed a script (Campbell and Muntzel 1989:181). Skills can slide within a single lifetime, a scribe going from competence to increasing disuse and deficient recall. For this reason, Andersen (1982:85) advises separation of individual from community patterns in examining language loss: there is a difference, for example, between attrition and a failure to acquire a dying language, and the same applies to script.

As with language, the context of script obsolescence may be abrupt and radical, involving the extermination of the scribes or vigorous repression of their craft, or it may experience "gradual death" as competence recedes toward desultory, defective use (Campbell and Muntzel 1989:182-86). The process of "tip" from one precarious state to another relates to the "ecology" of the script, that is, to its position in relation to its society and culture and to other scripts (Haugen 1971:25). The system of valuations in which scripts are embedded is crucial - which are prestigious, which are not, which serve general functions, which serve a more specialized purpose. Such aspects of the setting may also explain why certain scripts hold on against potent, disabling forces. Gradual obsolescence may involve a shift to a dominant script while retaining a niche in which an older script persists. Thus, after the introduction of the Greek alphabet on Cyprus by the seventh century b.c., the local syllabary probably survived because of its relation to the goddess cult of Paphos: when the cult declined in the Hellenistic period, so did the use of the syllabary (Bazemore 1994:290). Similarly, the peasant runic of Dalarna, Sweden, was used until the late nineteenth century by people who strove to preserve a distinctive sense of community, perhaps with the assistance of antiquarian-minded priests (Gustavson and Hallonquist 1994:171, 176): its terminal or last writers surely lived into the twentieth century (Williams 1997:177, fig. 1). Alternately, some scripts follow a "latinate" pattern, in which writing survives only in elevated or highly restricted contexts. In an alphabetic context, a particular form can have major cultural significance, as with Black Letter style (Fraktur) in Germany until the mid-twentieth century.

The preservation of languages concerns highly emotive issues of cultural diversity and ethnic identity (Dorian 1998:5; Garzon et al. 1998:169-70; Crystal 2000:66-67). The same is true of scripts. Consider the romanization of Turkish in the attempt to link Turkey with Europe, the switch in Azerbaijan from Cyrillic to roman script, in emulation of western Turks, and the use of distinct scripts to write what are essentially single languages (Serbian and Croatian, Urdu and Hindi, e.g., Mobbs 1981; Turvey 1984; Underhill 1976). In con- 
trast, the effort to resuscitate one extinct script, Mayan glyphs, seems less an attempt to replace Roman writing in Guatemala than an ephemeral nod to indigenous cultural autonomy (cf. Sturm 1996).

An unanswered question is how script obsolescence is ultimately comparable with language loss in a deeper, structural sense. Do the simplifications (loss of complexity) and reductions (defectiveness) documented in language death also occur in writing? Do features from a dominant script slip into a subordinate one (Andersen 1982:95)? Does the signary become impoverished in terminal or late script communities (Andersen 1982:93)? Do scripts, like language, experience moments of equilibrium followed by punctuation, divergence, and extinction (Dixon 1997:68-73)?

The examples that follow, organized in rough chronological order (Egyptian, cuneiform, Mayan, see Table 1, Fig. 1), two of uncertain connection in their origin (Egyptian and cuneiform), one securely separated (Mayan), cannot represent a full typology of script decay along the lines just sketched, but they do exemplify some of the external and internal variables present in most instances of last writing (compare Grenoble and Whaley 1998: Tables 2.1, 2.3; see also Edwards 1992). In the case studies we examine three possible explanations for script obsolescence: (1) a sociolinguistic explanation, in the sense of a correlation between the decay and disappearance of writing and a loss of prestige; (2) a "sphere of exchange" model (John Monaghan, personal communication, 2002), in which writing, like money, can be general purpose or restricted to certain kinds of transactions; and (3) a "demographic" explanation, in which the smaller the number of writers and readers, the smaller the chances of cross-generational transmission.

\section{EGYPTIAN}

Indigenous, civilizational values and practices, including those of writing, remained active in Egypt well into Roman times, more than four hundred years after the Macedonian conquest of the country in 332 B.C., the introduction of Greek as the language of the rulers and normal instrument of administration, and the rise of Alexandria as the country's principal, Greek-speaking city. Unlike our other examples, Egyptian possessed several script types that were in simultaneous use. In Ptolemaic times much administration for the indigenous majority continued to be in Egyptian demotic, the cursive everyday script of the period, but the rulers favored Greek for legal use, and far less demotic than Greek survives on papyrus from the Graeco-Roman period (the ratio of material on more durable materials is difficult to assess).

Conditions favorable to a cultural fragmentation of Egyptian writing had developed from about 1100 B.C., as script forms proliferated and became less mutually commensurable, while usage of the principal traditional forms began to be confined to fewer people. It is therefore desirable to sketch longterm patterns before focusing on the Roman and Byzantine periods, during 


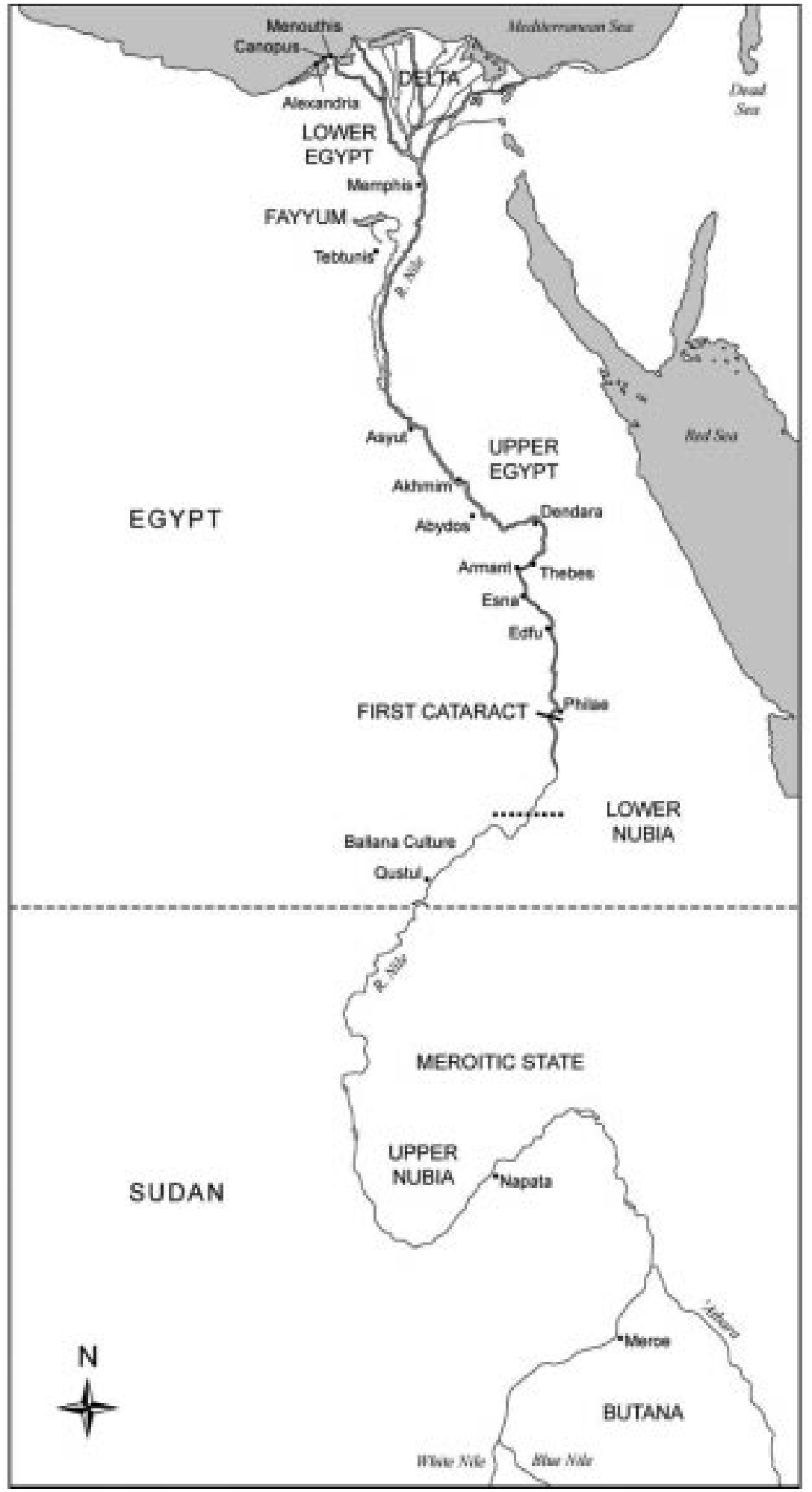



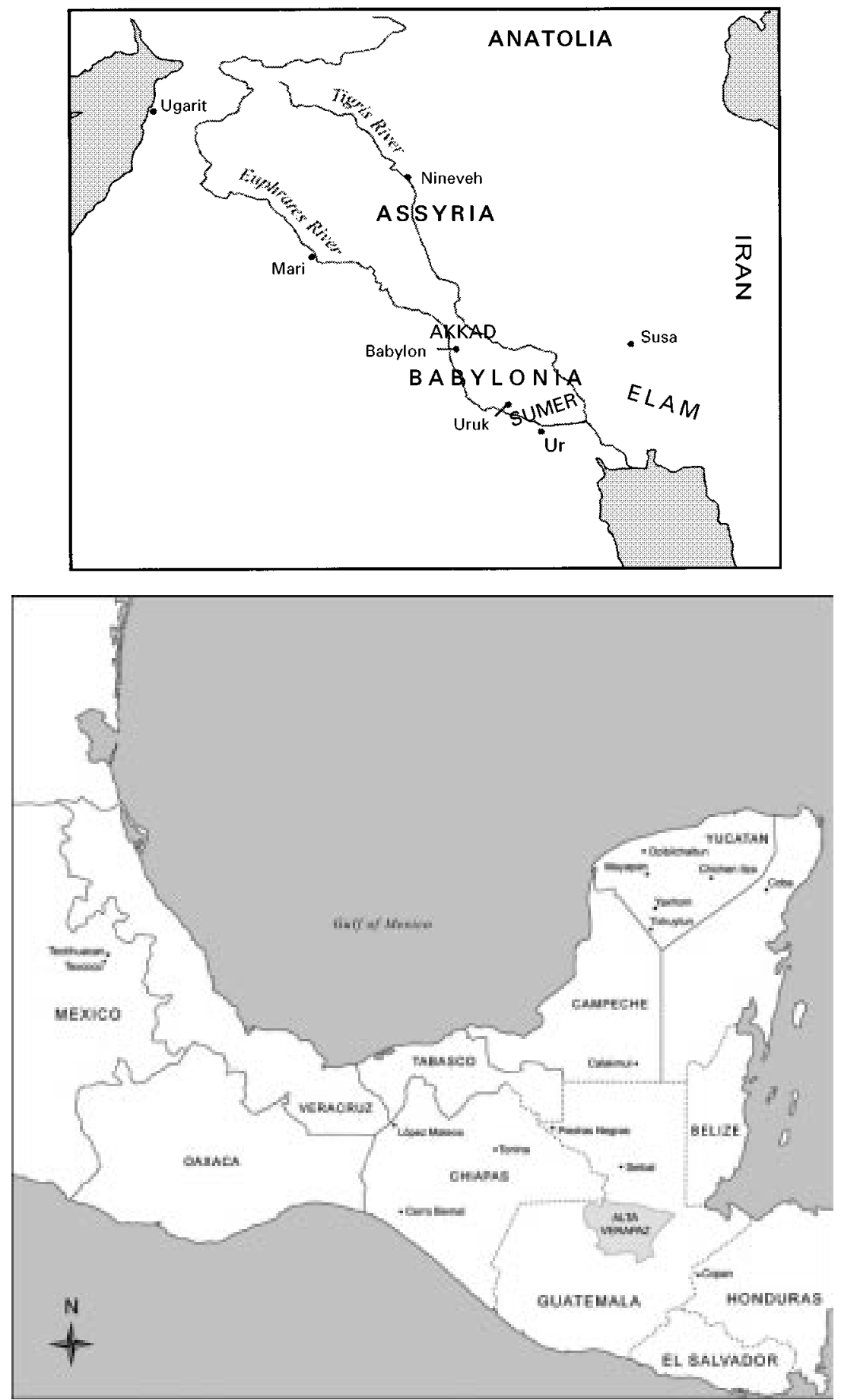

FIGURE 1. Egypt, Mesopotamia, and the Maya region, showing relevant sites (prepared by Scott Ure). 


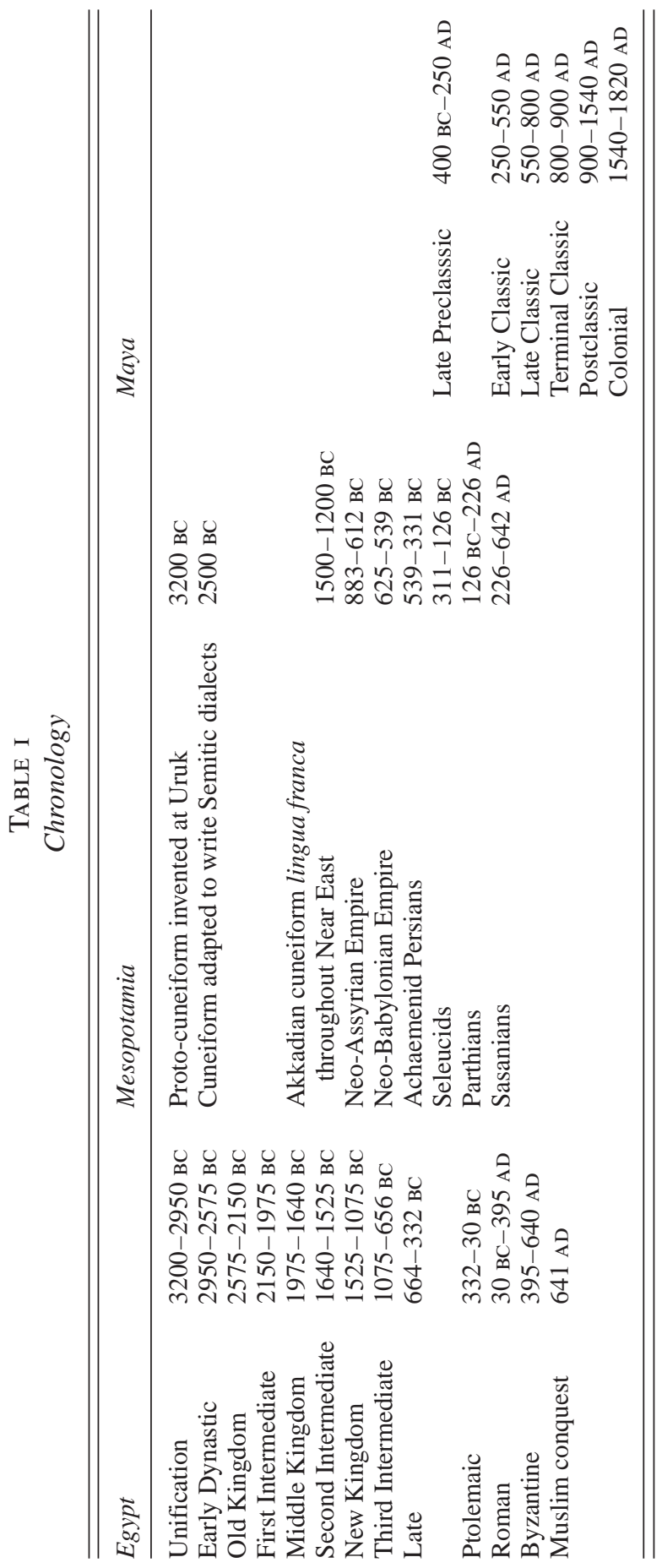


which the system finally fell out of use (for introductions, see Davies 1987; Ritner 1996).

Present-day classifications of Egyptian writing are influenced by Greek writers, notably the early Christian Clement of Alexandria (second to third centuries a.d.), whose Stromata include a brief but well-informed description of the system (V, IV, 20-21; 1981:58-61). This speaks of "epistolographic" ("letter-writing," now known as demotic), "hieratic" (priestly), and "hieroglyphic" (sacredcarved). This division into three scripts is generally seen as going back to the Late Period, after about 700 b.c. Because the first term of Clement's triad was not a very ancient form (see below), scholars seldom emphasize the analogous tripartite division of earlier scripts, referring instead to two (as did the fifth-century b.c. Greek Herodotus, II, 36). This issue of classification must be addressed briefly.

The traditional forms of Egyptian writing are now generally termed "hieratic," "cursive hieroglyphic," and "hieroglyphic" (for usages, see Table 2). The dominant form was hieratic, which was the cursive medium of everyday administration and of literary production, used mainly on perishable materials. (The meaning of the term "priestly" [hieratic] is appropriate only to its late usage, but no alternative designation has gained acceptance.) Literacy was taught through hieratic and/or cursive hieroglyphic, while hieroglyphic, the monumental, pictorial form which is now seen as emblematic of Egypt, was used essentially for display among the elite (including communication with the gods), even if a few signs, such as the ubiquitous $f$ ' $n h$ anx "life," may have been very widely known. From the invention of the script in the late fourth millennium b.c. onward, "monumental" - that is, hieroglyphic — and cursive forms existed (Dreyer 1998) and could be transposed sign for sign into each other. By the late third millennium, hieroglyphic inscriptions show signs of having been worked up from drafts either in hieratic (e.g., Mathieu 1996) or in cursive hieroglyphic. The latter is a third, intermediate script, used notably for religious texts, that seems also to have been the main vehicle for instruction in calligraphy and that mediated between the other two, as well as providing a suitable form for writing culturally central materials on the normal material of papyrus.

By the New Kingdom (from ca. 1500 b.c. hieratic tended to divide into subtypes. Everyday administrative writing was relatively unpolished, while elegant and careful styles were used for central chancery documents and for literary texts. From around 1200 b.c., religious texts, such as the Book of the Dead, began to shift to hieratic from cursive hieroglyphic. This development took root in the Third Intermediate period (c. 1075-656 B.C.), when distinct documentary styles of writing emerged both in Upper Egypt, leading to "abnormal hieratic," attested principally from the eighth and seventh centuries b.c., and probably also in the dominant north (Memphis and the Delta), where demotic crystallized by around 700 в.C., superseding abnormal hieratic in the south by about 550 в.C. (Vleeming 1981:36). From then on, demotic was the normal form for everyday, non-literary writing, and hieratic gradually disappeared 
from that sphere. Concomitant with the emergence of this fourth script form was the virtual disappearance of cursive hieroglyphic. Later hieroglyphs on papyrus tend to be essentially the same as monumental ones, rather than having the distinct sign forms of cursive hieroglyphic, and are used for elaborate, partpictorial compositions that are not attested on any other medium (e.g., Beinlich 1991).

Thus, from the third millennium onward, Egyptian writing had three main script forms (Table 2). The identities of two of the three scripts changed, but the triscript principle remained. Such divisions of script forms, while only slightly present in Mesopotamia (compare the lapidary Code of Hammurabi with the paleography of a letter from that king's chancery), are not unique; different varieties of Chinese or of Arabic are obvious analogies. However, the integration of hieroglyphic writing into pictorial and monumental forms, which is closely paralleled in Mesoamerica, imparted great cultural salience to that script, even though it was not a utilitarian form and few seem to have been competent in it. This combination of limited currency and prestige meant that Egyptian writing was culturally significant even when it was not understood by those who commissioned or inscribed it. As with many aspects of high cultures, transmitting such a multilayered legacy involved a heavy investment.

The introduction of demotic and concomitant realignment of script types meant that hieroglyphic and everyday writing ceased to be commensurable. Whereas hieratic can be transcribed into hieroglyphic, such a transposition is artificial for demotic and would probably not have been done in antiquity, even though hieroglyphic and hieratic sign forms continued to provide orthographic models for some newly introduced words in demotic. This freeing of hieroglyphic from everyday script opened the way to a proliferation in its sign repertory from a few hundred signs to some thousands, and to the creation of many new sign values through inventive application of the script's principles. The expanded script was used on royal and non-royal monuments, notably in temples for the former and temple statues for the latter, reaching its high point in Roman times, when some of the most complex of all inscriptions were carved (e.g., Sauneron 1982). No text states what was the purpose of this elaboration, but everything points to its being a celebratory integration of the maximum meaning in inscriptions, many of which were carved in places where they could hardly be read, because they were too remote or dark to be seen, or because few had access to their locations. The inscriptions addressed the gods and the tiny peer group of their creators far more than people in general. Yet, those which were carved in accessible positions were often among the most complex, and some remain difficult to decipher. This does not mean that their content was deliberately obscured, but rather that they displayed the greatest virtuosity in the interplay between choice of signs and verbal content. Their topic, which in several cases is the construction history of a temple (e.g., Dümichen 1877), is not secret, so that their elaboration should be interpreted in other ways. This de- 
TABLE 2.

Egyptian scripts and text genres in the late New Kingdom (c. 1200 b.c.) and the Graeco-Roman period (from Baines 1983)

\begin{tabular}{|c|c|c|c|c|}
\hline & \multicolumn{2}{|c|}{ Late New Kingdom (c. 1200) } & \multicolumn{2}{|c|}{ Graeco-Roman } \\
\hline & script form & language form & script form & language form \\
\hline $\begin{array}{l}\text { monumental } \\
\text { inscriptions }\end{array}$ & hieroglyphic & $\begin{array}{l}\text { Classical } \\
\text { Egyptian }\end{array}$ & $\begin{array}{l}\text { hieroglyphic; some } \\
\text { demotic }\end{array}$ & $\begin{array}{l}\text { Classical Egyptian; } \\
\text { demotic }\end{array}$ \\
\hline scribal training & $\begin{array}{l}\text { cursive } \\
\text { hieroglyphic }\end{array}$ & $\begin{array}{l}\text { Classical } \\
\text { Egyptian }\end{array}$ & demotic & demotic \\
\hline $\begin{array}{l}\text { official religious } \\
\text { texts }\end{array}$ & $\begin{array}{l}\text { cursive } \\
\text { hieroglyphic }\end{array}$ & $\begin{array}{l}\text { Classical } \\
\text { Egyptian }\end{array}$ & $\begin{array}{l}\text { hieroglyphic; } \\
\text { hieratic; demotic }\end{array}$ & Classical Egyptian \\
\hline $\begin{array}{l}\text { literary texts; } \\
\text { religious and } \\
\text { magical texts } \\
\text { for everyday use }\end{array}$ & hieratic & $\begin{array}{l}\text { Classical and } \\
\text { Late Egyptian }\end{array}$ & demotic & demotic \\
\hline $\begin{array}{l}\text { business and } \\
\text { administration }\end{array}$ & hieratic & Late Egyptian & demotic & demotic \\
\hline
\end{tabular}


velopment of hieroglyphic culminated when Greek had long been the official language and had a larger literate community than Egyptian.

Parallel with the specialization of hieroglyphic, hieratic continued to be used on papyrus in the world of the temples, to which traditional high culture was increasingly confined (exceptional third-century a.d. graffito in mixed hieratic and demotic: Griffith 1935:58 no. Ph. 68). As late as the third century a.d., religious texts and significant compositions, such as lists of categories of the world (e.g., Osing 1998; Osing and Rosati 1998), tended to be in hieratic, which had replaced cursive hieroglyphic in these and some other uses. The latest works of belles lettres in hieratic may date between the seventh and fourth centuries b.c. (Verhoeven 1999), but that function was gradually taken over by demotic.

Abnormal hieratic and demotic were long considered to be utilitarian, with demotic becoming a vehicle of general high culture only in the Ptolemaic period. A literary text in abnormal hieratic (Baines et al. 1998) and fourth-century b.c. manuscripts of literary texts in demotic (e.g., Smith and Tait 1984) raise doubts on this point, as does the possibility that the largest single early demotic text (fifth century b.c.), should be classified as literary (Vittmann 1998; an issue not tackled there). Demotic was used for some religious texts (e.g., Depauw 1997:94-95, 116-21). Probably from the beginning, therefore, demotic brought another strand to all uses of writing, except for the "monumental" style of hieroglyphic. It was used for some public inscriptions in the Graeco-Roman period, notably the decrees inscribed in hieroglyphic, demotic, and Greek that provided the point of departure for the decipherment of Egyptian. The demotic in these, however, seems to be inscribed more as a complement to the display of the Greek text than as part of indigenous writing practice. Demotic is far more economical than earlier Egyptian scripts in its notation of words, but, like many very cursive scripts, it operates largely in terms of sign groups or word groups - in part through its indirect inheritance of the determinative system of hieroglyphic — rather than individual graphemes. It therefore required frequent use for proficiency to be maintained.

As a primarily administrative and everyday script, demotic was the most widely used form of the Late and Ptolemaic periods (for education, primarily in Greek, see Cribiore 1996). Its effective incommensurability with the other scripts meant that it became largely self-contained. While it possessed uniconsonantal signs of potentially universal application, its mainly logographic, signgroup-based orthography was never abandoned. Like hieroglyphic - and like Mayan writing - it remained attached to a single language. Although a subset of its signs was used to write Aramaic uniconsonantally (e.g., Vleeming and Wesselius 1985), that practice did not take hold. Demotic calligraphy was also used as the model for Meroitic cursive, introduced in Sudanese Nubia around the second century b.c. to write a language unrelated to Egyptian (e.g., Millet 1996; Leclant et al. 2000). However, that script is consonantal/alphabetic (with 
graphic word dividers), and its structure was evidently inspired by other alphabetic scripts, whether Semitic or Greek (the Meroitic monumental script, which is also alphabetic, was modeled on Egyptian hieroglyphs). Meroitic presumably used Egyptian models for signs because of their cultural prestige, since it did not borrow the writing system.

Demotic had an uneasy relationship with Greek. When demotic became Egypt's everyday script, it was probably seen as an advance in terms of the language, of which it wrote a different stage from earlier scripts, and in its relatively simple and rapid sign forms (hieratic was largely indifferent in the stage of the language it wrote). About three hundred years later, when Greek became the preferred language and script of administration, demotic adapted principally by exclusion. The language it wrote developed relatively little and gradually became very far from the spoken. In relation to the wider linguistic environment, the principal Greek elements in demotic are proper names (Clarysse et al. 1983); for the rest, Greek had little influence on demotic (Ray 1994). Its successor, Coptic, which is Egyptian written in Greek letters augmented by a few alphabetically used signs that were adapted from demotic, contrasts markedly here. "Old Coptic," known from a few pre-Christian texts of the second to third centuries a.d., most of them magical, developed out of Egyptian uses of Greek letters from the Ptolemaic period on (Quaegebeur 1991; Satzinger 1991; Emmel 1992). Some Old Coptic texts are difficult to decode because their phonology is far removed from their Classical Egyptian language of up to 2000 years earlier (Osing 1976). Christian Coptic, in which a substantial literature survives from the fourth century a.d. on (Orlandi 1991), represents a later stage of the same language as demotic but is pervaded by Greek, partly in Christian vocabulary, but also in ordinary words down to particles (Layton 2000:§§5, 7).

Thus, traditional Egyptian culture kept to its own language in the bilingual and multilingual Graeco-Roman environment, in which Greek had prestige in certain domains but was not perceived as the country's traditional cultural language. The elite guardians of indigenous tradition, whose culture was focused around the temples (e.g., Vleeming 1994), deliberately excluded Greek from written Egyptian, even in everyday uses, presumably safeguarding its "pristine" character. From the Roman conquest of 30 b.c. on, the prestige of Greek was reinforced by administrative discrimination in its favor. While Latin had little impact in Egypt and the eastern Roman Empire, the fact that it was the language and script of the rulers may have made them less tolerant of local written languages except for Greek than they might otherwise have been. Although Egypt's Roman rulers accorded value to the traditional civilization and until the second century a.d. were generous patrons of its principal symbols, the temples, their policies eliminated the indigenous upper elite, leaving a learned body of priests and other literate people who did not have the cultural or economic status of their ancestors (Bagnall 1993). Around the mid-third century a.d., Egyptian writing in hieroglyphic was confined to a few temples and some burial con- 
texts, with demotic being used in temple scriptoria and in graffiti on the walls of the pilgrimage site of Philae near the frontier with the Meroitic state and its successor, the Ballana culture of Lower Nubia (Griffith 1935). By that date, demotic was no longer used for administration. From 313 the emperor Constantine committed the empire to Christianity, and from 395 traditional temples were decreed to be closed, although Philae remained in use until 565 (Winter 1980). Philae bears the latest identifiable hieroglyphic text, dated by an accompanying demotic graffito to 394 , and the latest demotic graffito without accompanying hieroglyphs, from 452 (Griffith 1935:126-27 no. Ph. 436; 102-3 no. Ph. 365).

This apparent significance of the remote south may be misleading, because towns such as Menouthis near Alexandria in the Nile Delta maintained a traditional cult well into the fifth century a.d. (Frankfurter 1998:40-41, and passim). Since ancient sites survive poorly in the north, particularly in the humid and heavily developed Delta, we are unlikely to discover when specific usages disappeared from there. With these provisos, however, it is possible to situate the disappearance of Egyptian writing in time and to discuss what were its causes, and to a lesser extent how the system withered.

The loss of writing relates to its function and social role, both positively and negatively. In a positive sense, the presence of writing can make an artifact or a building functional, whether or not whoever benefits can read what is written. That consideration applies more strongly to Egyptian writing in works of art than in everyday administration and communication, or in technical and high-cultural uses. In a negative sense, if writing's cultural or practical functions lose their role and value, or are superseded by other scripts or practices, any particular form of writing will almost inevitably disappear. That consideration relates perhaps most closely to administrative writing. Many functions were ultimately taken over by Greek writing, but much of traditional civilization was bound into practices and genres of artifact that ultimately ceased to carry their traditional meanings. It is not simple, however, to correlate the disappearance of other practices with the loss of the script, because writing became reduced on traditional artifacts long before they ceased to be made. This area exemplifies the complex interweaving of writing and civilizational values. In contexts such as the mortuary preparations of individuals, Egyptian writing disappeared before artifacts and practices associated with it ceased, whereas in temples it survived for some time after investment in their construction dried up.

The positive side of the functional argument applies even to very early times. Because hieroglyphs formed a display script, they could operate without bearing a specific linguistic meaning. Many sealings of the Early Dynastic period have hieroglyphic "inscriptions" that cannot be read and form visual as much as textual compositions (e.g., Baines 2003). These appear to be of lower status than intelligible examples and testify to writing's prestige, which outstripped 
the availability of trained seal-carvers - unless access to writing competence was restricted. Much later Third Intermediate period coffins, some from rarely preserved burials of an intermediate social stratum, often bear pseudo-hieroglyphs (Raven 1991: e.g., 3 and pls. 6c, 17, 19, 25; in a different style: Detroit DIA 90.1S11799). These are captions to figures of deities and demons that would be highly standardized and familiar to anyone who could read hieroglyphic; their incorrect forms therefore demonstrate scarcely any understanding by the craftsmen, and probably their patrons. Some of the signs graphically resemble hieratic, with which most of the literate would have been more familiar, but they are not legible in that script form either. On a few objects, blank rectangles and bands were left for writing according to the standard pattern of inscribing in hieroglyphic, but these were never filled in, and it is unlikely that any inscription was planned. Here as in many other cases where writing spaces were left blank in the first millennium b.c. and later, the evocation of writing's potential presence evidently sufficed.

A comparable process of decay in hieroglyphic has been analyzed by Heike Sternberg-el Hotabi for magical stelae of the Late and Graeco-Roman periods (1994; corpus: 1999). These were inscribed with standard texts that become progressively more schematic and less intelligible (Fig. 2), presumably without unduly affecting their efficacy. A partial parallel is on the magnificent traditional Egyptian sarcophagus of a Greek high official, Dioskourides, which was inscribed about 140 B.C. with texts of excellent appearance that are full of errors and defective orthography (Collombert 2000). The loss of competence on the stelae was contemporaneous with the greatest extension of meaningful hieroglyphic in temple inscriptions. The differences between these patterns of development relate to the availability of resources as well as to the perceived efficacy of hieroglyphic inscription in temples. The latter must have meant more in cultural terms than because of any necessity that they be inscribed. As Claude Traunecker has emphasized (e.g., 1991), modest temples, which were the vast majority, were generally uninscribed but presumably functioned no less than the grander inscribed ones that received lavish state support. By the late second and early third centuries a.d., the quality of inscription of hieroglyphic texts even in major temples declined (Fig. 3). Serge Sauneron remarked of part of the temple of Esna: "In these texts . . . we witness the final manifestations of hieroglyphic writing - and observe its total decrepitude: signs are omitted, entire groups are written in the reverse direction to the rest of an inscription; numerous hieroglyphs are not understood at all and are decomposed into strange fragments; the carving even reproduces forms that do not correspond to anything otherwise known and are often nothing more than crude errors" (1975:v).

The decline becomes evident a couple of generations before the latest surviving scenes inscribed with an emperor's name, also at Esna, from the reign of Decius (249-51 A.D.). Later materials are not in the same formal manner, 


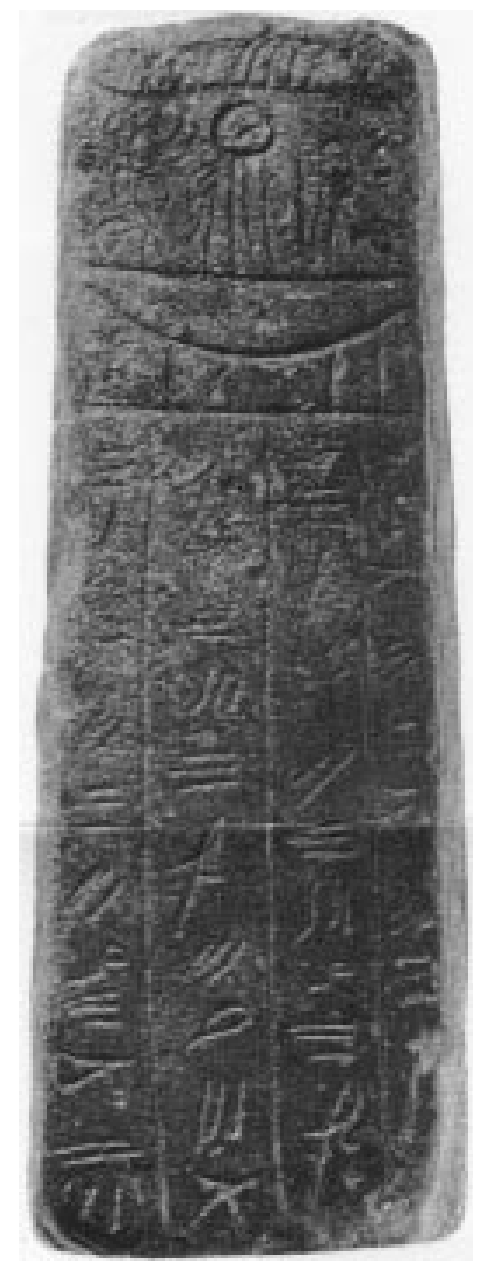

FIGURE 2. Magical stela of "Horus on the Crocodiles," back, pseudo-hieroglyphic inscription. Perhaps first century a.d. Oxford, Ashmolean Museum 1886.809. (Sternberg-el Hotabi 2000:74 and pl. LIX, courtesy Ashmolean Museum).

but hieroglyphic continued to be used for a century, notably in stelae for the mortuary cult of the Buchis Bull at Armant, of which the latest known dates to 340 (Grenier 1983). This last example, however, shows a loss of the Egyptian context because it is dated by the late Roman Era of Diocletian (began 284), not by the year of reign of Constantius II, under whom it was made. (The Philae graffiti cited above are dated by the same era.)

Usage of hieroglyphic in temples declined more slowly than on other monuments. The latest known non-royal biographical text, from the mid-second 


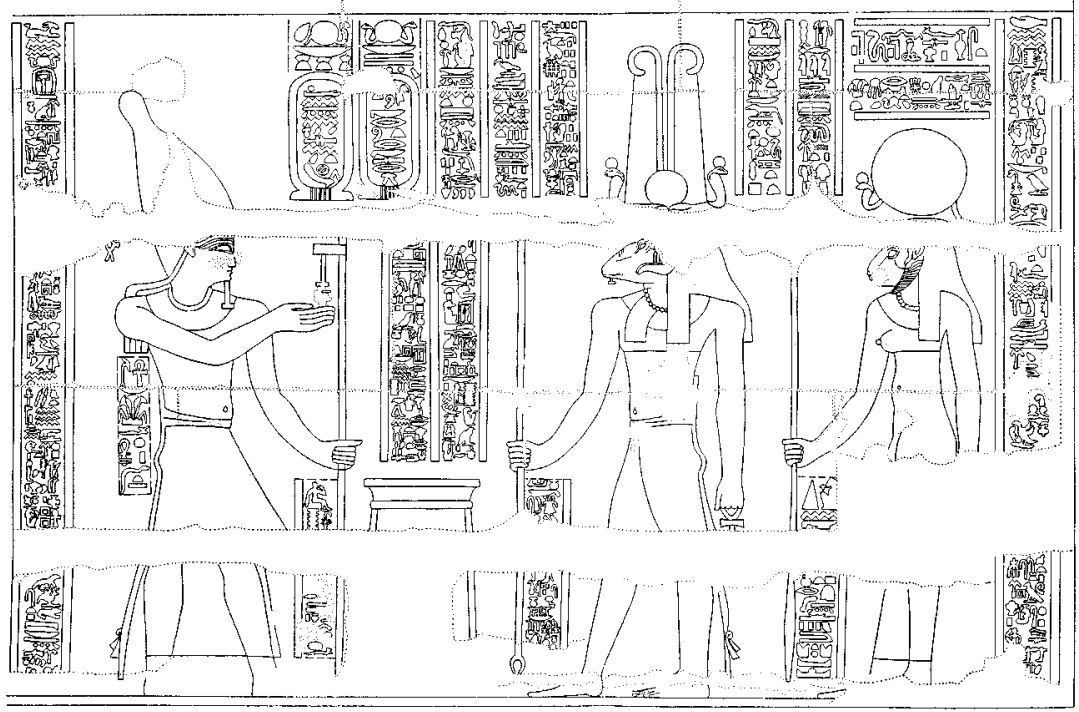

Figure 3. The Roman emperor offers to Khnum and Menhit; temple of Esna, south inside wall, first register, east scene (Reign of Caracalla a.d. 198-217, after Sauneron 1975: facing p. 76).

century, comes from the major Nile Valley center of Akhmim. It shows no diminution in competence of composition and is in the same Classical Egyptian that had been used for two thousand years, but is completely isolated (Scharff 1927; Derchain 1987); by that date the indigenous elite had lost most of the wealth needed for such objects. Mortuary material that kept fully to traditional Egyptian culture continued to be made in very small amounts for another century and included some hieroglyphs (Riggs 2002).

Despite this pattern of decline, traditional Egyptian culture remained active in temples until the late third century. In the provincial town of Tebtunis in the Fayyum, papyri continued to be inscribed with complex literary and encyclopedic compositions in hieratic and demotic (e.g., Frandsen 1991; Frandsen and Ryholt 2000; on scribal knowledge in the Roman period, see Widmer in press). It is not possible to say whether texts were being composed or only copied, but the range of material is impressive. At least as much activity should be posited for places like Akhmim, where conditions do not favor the survival of such evidence. The third-century date fits with the sporadic later survival of hieroglyphic to give a picture of a very restricted but still viable written culture encompassing texts in a number of genres. By this date, however, Greek was overwhelmingly dominant. The long hieratic encyclopedic text from Tebtunis (Osing 1998), which is composed in Classical Egyptian (the manuscript is second century a.d.), has numerous supralinear pronunciation glosses in demotic and in Old Coptic (i.e., Greek letters, Fig. 4), confirming that hieratic was not 


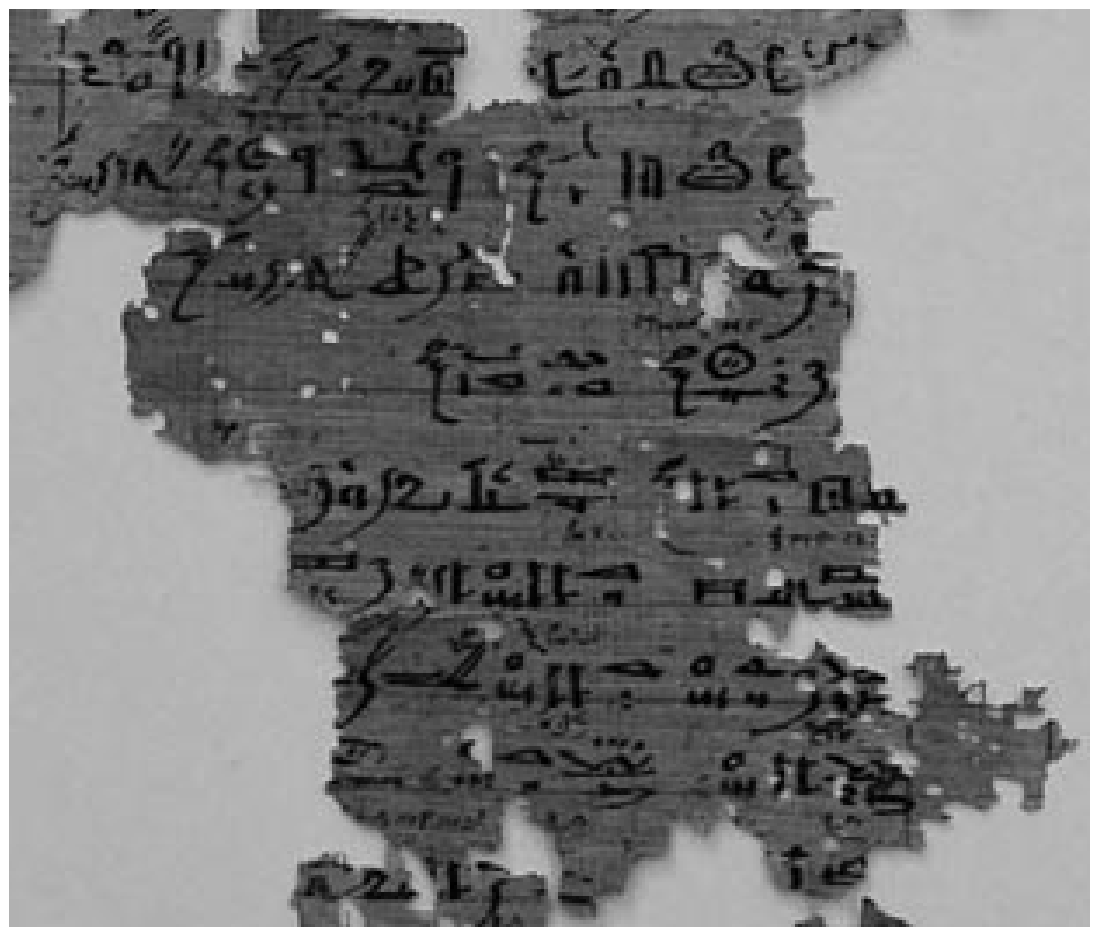

FIgURE 4. Section of Papyrus Carlsberg 180, a third century a.d. manuscript from Tebtunis of an "onomasticon" (list of significant categories). The text is in hieratic with very small supralinear glosses in demotic and Old Coptic (courtesy Carsten Niebuhr Institutet, University of Copenhagen).

the scribe's first script. Presumably that was Greek, perhaps with demotic second, and hieratic and hieroglyphic equal third.

Demotic all but ceased to be used for business and legal purposes soon after the Roman conquest (Lewis 1993), 250 years before these materials were written. An exception is a lease of a gardening plot inscribed on a large third-century a.d. pot from Thebes (Parker 1940). This text appears superficially functional (the writing medium is not unparalleled), but its terms are over-elaborate and, as Mark Depauw suggests (1997:96), it is more likely to be a scribal exercise than a utilitarian document. One suspects that the exceptional choice of language made a strong cultural statement, of a type that is more evident in roughly contemporaneous burial assemblages (Riggs 2003). If so, the text is within the pattern in which Egyptian script and language were used where they were culturally advantageous - in however limited a way-in relation to Greek. Demotic was not culturally prominent in the same way as hieroglyphic and hieratic were, but it could serve the same ends and continued to do so, at least in graffiti, for some time after the latest securely dated hieroglyphs. 
This final survival is significant, because the use of demotic required learning a writing system that was entirely different from Greek and very far from spoken language. The extant material is insufficient for a specific analysis of how the writing system declined (see Tait 1994; 2001, regarding its viability for people with limited literacy). Egyptian orthography of all periods and scripts was so variable that it would be difficult to establish criteria of competence for its use comparable to those developed for language loss.

These processes can be summarized as occurring in three stages. First, from the Roman conquest onward Egyptian writing, which was no longer the majority vehicle of literacy, was strongly discriminated against in administration. While demotic remained fully functional, its everyday use became rare and Egyptian writing focused around the temples, where hieroglyphic and other traditional forms continued to flourish. Knowledge of them elsewhere was in decline but maintained a tenuous existence in mortuary contexts. Second, the political and economic crisis of the Roman Empire in the third century a.d. (Potter 1990:3-69) brought a great diminution of state patronage for traditional high culture, including temples and their associated writing, although indigenous religious practices by no means died out at a local level (Frankfurter 1998). Greek-style institutions, which were largely in the hands of local, culturally Greek elites, continued to expand in provincial Egypt. This stage was probably the decisive one for the obsolescence of Egyptian writing. Third, in the fourth and fifth centuries all indigenous forms of Egyptian writing, with demotic the last survivor, disappeared and knowledge of them was lost.

In third- and fourth-century Egypt several religions competed both with one another and with traditional religion and its civilizational basis. Gnosticism, Manichaeism, and Christianity were the principal new arrivals. The last of these became dominant by the end of the fourth century. The spread of these religions cannot explain the decline of traditional Egyptian civilization, which began centuries earlier. Rather, the legal and fiscal constraints and discriminations of Roman rule, in a context that was already bicultural, together with the eclipse of the highest indigenous elite, were exacerbated by the crises of the empire, depriving central symbols both of authority and of economic support and thus opening the way to alternatives, one of which, Christianity, came to enjoy imperial support. In its reception of those alternatives, Egypt as a whole-the chōra, "countryside" in Greek parlance-lagged behind the mixed but culturally Greek metropolis of Alexandria; but the temporal difference between the two regions is difficult to estimate.

The identification of civilization and writing was central to the disappearance of Egyptian scripts, but does not explain the precise pattern of their decline. Indeed, Christianity became domesticated, bringing a revival of "Egyptianness" that was expressed in Coptic writing, not in Egyptian scripts, which were too heavily freighted with traditional religion and tied to the world of the temples to be acceptable for a radically different religion (only a few cursive 
and non-pictorial signs were taken over into Coptic). Until the late twentieth century a.d. Coptic Christianity maintained a dogmatic distance from the metropolitan forms of Byzantium and Rome that seems to have been partly motivated by this desire for distinctiveness. This distinction manifested itself in the use of Coptic in some areas for administrative in addition to religious purposes, in a context where Greek continued to be the official language until well after the Islamic conquest of 641 (e.g., Clackson 2000; Wilfong 2002). Coptic ceased to be a spoken language by about 1000 , but it remains the liturgical language of the church in Egypt.

The principal constant element in this narrative is the identification of writing with language, religion, and civilization. Here Coptic, as a minor variant of Greek writing that notates a completely different language, exhibits a civilizational tie that partly parallels its direct ancestor Egyptian. Earlier, a considerable investment was necessary to sustain a multi-script written culture. Rulers were willing to make that investment, either because they were directly or indirectly integrated with the culture and appreciated its values, or because they saw such expenditure as necessary to legitimations and processes of rule. Egypt retained its traditional culture and writing more than did most of the Roman empire. While early emperors invested heavily in the culture, building as many temples as any of their forerunners, from the late second century they either were not interested in continuing the practice or did not have the resources to do so. From the early fourth century they were positively hostile to it.

\section{CUNEIFORM}

Cuneiform writing (Cooper 1996; 2003; Englund 1998; 2003) was invented around 3200 B.C. in Babylonia (southern Mesopotamia) at Uruk, the first great city (Liverani 1998), and was still in use there in the second century B.C., 3000 years later. Cuneiform tablets from the city of Babylon are attested late into the first century a.d., and probably continued to be written well into the second (Oelsner 1986; 2002). Cuneiform signs are configurations of wedge-shaped impressions made with a reed stylus on a clay tablet, or, beginning in the second millennium, on a wax-covered wooden tablet (Volk 1999:286-87); writing on non-impressible media — stone, metal, wood, plaster-was done for commemorative or decorative purposes only, for example on royal statues, palace walls, seals, and objects dedicated to temples (Cooper 1999).

Cuneiform writing is a logophonetic representation of language, that is, a cuneiform sign can stand for a word, or for a syllable used alone or in combination with other syllabic signs to phonetically spell out a word or bound morpheme (Cooper 1996). Mastery of the corpora of belle-lettristic, religious, and scientific texts required a knowledge of four hundred or more signs; for ordinary purposes - letter writing, administration, legal documents - a scribe could make do with fewer than two hundred signs, and, in some periods, only about one hundred (Michalowski 1994:59). 
First used to write the Sumerian language of the early inhabitants of southern Babylonia, cuneiform was by the middle of the third millennium b.c. being employed to write the Semitic dialects used in northern Babylonia, upper Mesopotamia, and northwestern Syria (Cooper 1999). From the middle of the second millennium b.c. to around 1200 B.C., the Semitic Akkadian language (Assyro-Babylonian) written in cuneiform was the lingua franca of the entire Near East, from Iran to Egypt and from Anatolia to the Persian Gulf (Moran 1992:xviii-xxii). In the third, second and first millennia b.c., Elamites, Hurrians, Hittites, and Urartians also adapted Sumero-Akkadian cuneiform to write their own languages (Gragg 1996). But the second millennium B.C., when the use of Sumero-Akkadian cuneiform was most widespread, also was the period during which the Semitic alphabet was invented and perfected for writing the native languages of the Levant and Syria (O'Connor 1996). The speakers of those languages abandoned the Akkadian lingua franca after about 1200 B.C.; from the beginning of the first millennium b.c., alphabetic inscriptions in Aramaic, Phoenician, Hebrew, Moabite, and other Canaanite dialects appear in increasing numbers, and Akkadian cuneiform was used outside of Mesopotamia proper only in the service of Assyrian or Babylonian imperialism.

In Mesopotamia, Sumerian, the first written language, had become extinct as a mother tongue by the early second millennium b.c. (Michalowski 2000), but down to the first century of our era it continued to be taught in schools and chanted in temples as what Walter Ong (1982:112-15) has called a "male language," a language learned primarily by males not as a mother tongue but as a language of religion and erudition, like Latin or rabbinic Hebrew in the Middle Ages. In the first half of the first millennium b.c., the Assyrian and Babylonian dialects of Akkadian came under increasing pressure from Aramaic. Despite the many scores of thousands of Akkadian cuneiform documents from both Assyria (until its fall at the end of the seventh century B.C.) and Babylonia, there is ample evidence that much writing was being done in alphabetic Aramaic on leather, papyrus, clay, and even lead (Tadmor 1991; MacGinnis 1995:122-23; see Fig. 5). It is impossible to determine what percentage of the population still spoke Akkadian when Cyrus the Persian entered Babylon in 539 B.C., but whatever the size of the Akkadian mother-tongue community (cf. Streck 1995:xxiiixxiv), a very large cuneiform script community continued both to transmit traditional Sumerian and Akkadian learning and produce Akkadian administrative and legal documents under Cyrus and his Achaemenid successors.

When Alexander marched triumphantly into Babylon in 330 B.C., Akkadian, too, in all likelihood had become a "male language" studied in schools that perpetuated ancient learning in the cuneiform script (Gesche 2000; but cf. Streck 1995:xxiv). The graduates of these schools became the scribes, administrators, and clergy of the temple communities that played central roles in the Babylonian cities of the Seleucid period (Spek 1987). Akkadian "still flourished" as a written language of religion, science, and law, and perhaps was even spoken by 


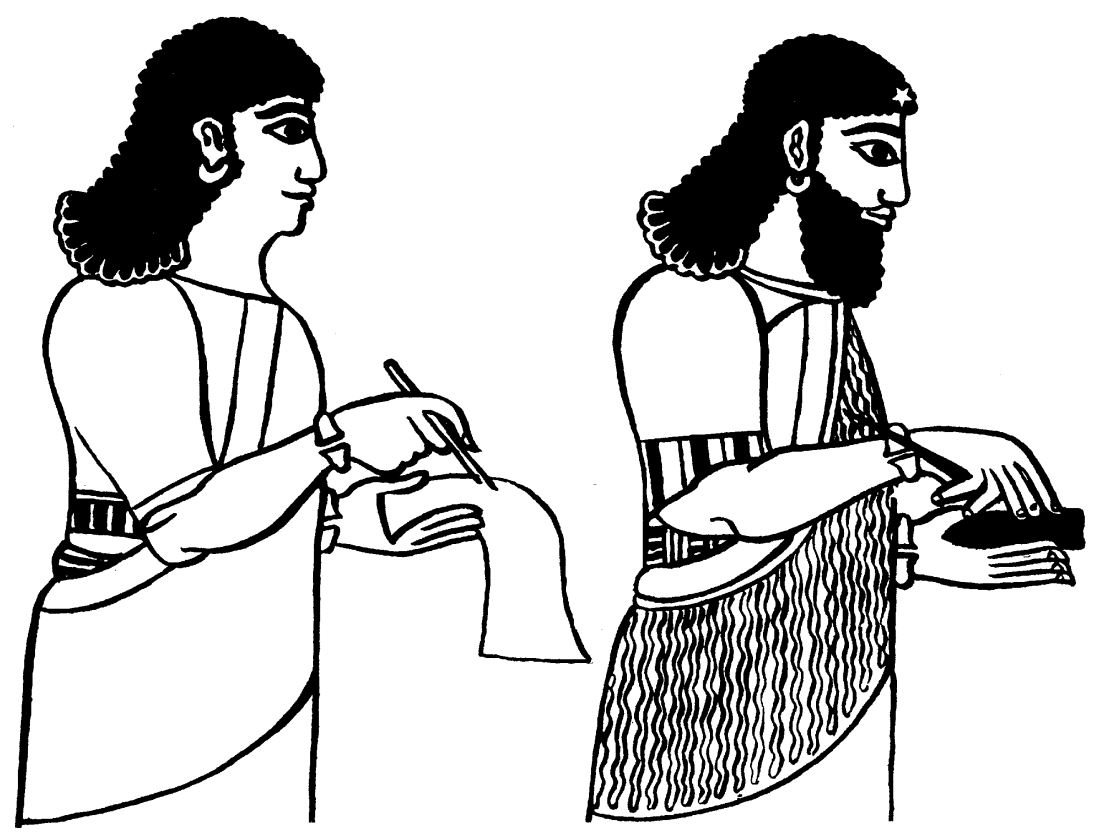

FIgURE 5. Two Assyrian scribes from an eighth century b.c. wall painting at the provincial capital Til Barsip in present-day Syria. The scribe on the left writes Aramaic on pliant papyrus or parchment, that on the right writes in Akkadian cuneiform on the more rigid clay tablet (as drawn for the covers of the State Archives of Assyria Studies series [Neo-Assyrian Text Corpus Project, Helsinki]).

officials within the temple communities, "even though the [cuneiform] scribe may have spoken Aramaic to his children or Greek to his tax official" (Geller 1997:45; cf. Spek 1998:255). But if cuneiform writing "still flourished" under the Seleucids, it was gradually restricted to ever more narrow areas of use, as Aramaic and now Greek became important languages for both private and official documents (Sherwin-White 1987:23-26), and certain taxable transactions had to be officially registered and hence executed in Greek (Doty 1977:323; Oelsner 1978:110). Private legal documents in cuneiform are not attested at Babylon after the middle of the second century b.c. (Oelsner 1986:197), and by the time Babylonia falls definitively under Parthian rule in 126 B.c. (Oelsner 1986:64; Wiesehöfer 2001:122-23) cuneiform is used exclusively in the temple communities and their schools. In addition to school texts, and the administrative documents and cult texts of the temples (Fig. 6), an extraordinary tradition of astronomical observation and calculation in cuneiform was maintained; the latest dated cuneiform text (Sachs 1976) is an astronomical almanac (Hunger and Pingree 1999:162-67) calculated for the year 75 A.D. It is, then, quite probable that cuneiform learning persisted into the second century of our era 


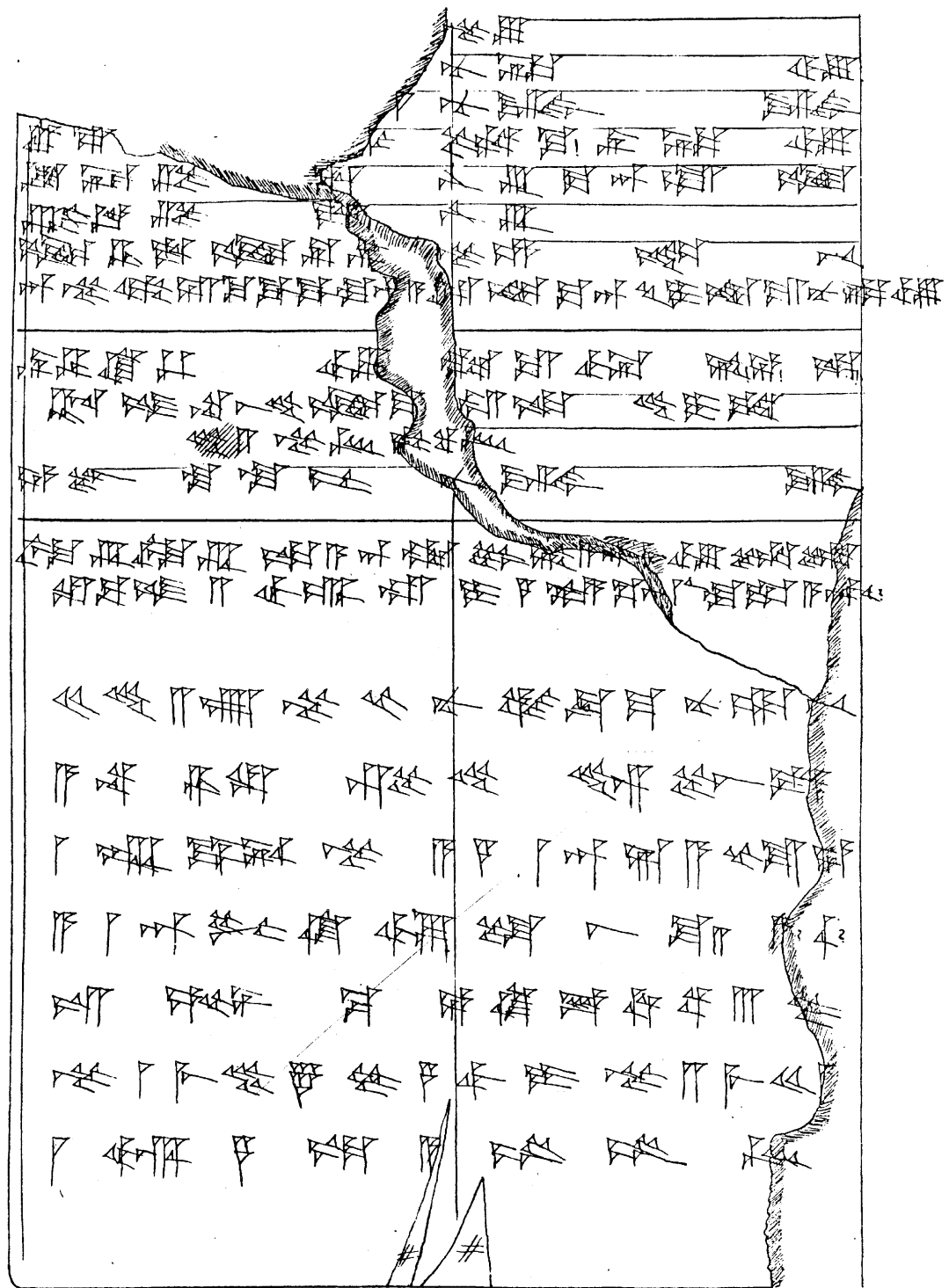

FIGURE 6. Reverse of tablet containing bilingual Sumero-Akkadian hymn, with colophon stating that it was written in Babylon in 90 b.c. (year 221 of the Seleucid Era and 157 of the Arsacid [Parthian] Era, Reisner [1896:no. 46]; cf. Hunger [1968:no. 147]). 
(Oelsner 2002:32); it certainly perished by the time of the Sassanian conquest of Babylonia in the mid-third century (Spek 1998:206-7), not to be revived until the brilliant decipherments of the mid-nineteenth century.

Despite every indication that outside the Babylonian temple communities Greek and Aramaic were the languages of written communication and record keeping in Parthian Babylonia, few documents in these languages have survived. The linear Aramaic and Greek scripts were written primarily on papyrus or parchment, which, unlike clay tablets, burn or disintegrate quickly (except in the very dry Egyptian desert or Dead Sea region). The only Aramaic or Greek writing unearthed in Babylonia from Seleucid and Parthian times is what happened to be written on clay or stone, including seal inscriptions preserved in sealings on clay bullae (Oelsner 1986: ch. 4). The temple scribes and officials who made up the cuneiform script community would have to have been at least biliterate (cuneiform and Aramaic or Greek) and were probably triliterate. In fact, certain peculiarities of cuneiform orthography in the first millennium b.c. can best be explained as interference from alphabetic Aramaic orthography (Streck 2001). It may be that familiarity with simpler alphabetic writing on light-weight and less breakable writing surfaces accelerated the abandonment of cuneiform for all but temple-related purposes.

The multiliteracy of the cuneiform script community is evident in a group of seventeen clay tablets that have been dubbed "Graeco-Babyloniaca" because they consist of school exercises in cuneiform on the obverse, with transliterations (not translations!) of the cuneiform in Greek letters on the reverse (Geller 1997; Fig. 7). The paleography of the Greek script dates the tablets between the second century b.c. and the first century a.d., and the content conforms to the kind of material found on Babylonian cuneiform exercise tablets of the late first millennium b.c. (Gesche 2000:184-85).

What is the purpose of the so-called Graeco-Babyloniaca? Undoubtedly the Greek transliteration on the reverse is to help the student learn how to pronounce the cuneiform signs on the obverse. Although Aramaic, not Greek, was certainly the students' mother-tongue (contra Gesche 2000:185), the Aramaic alphabet is, like other Semitic alphabets, primarily consonantal, leaving vowels imperfectly represented. The major innovation of the Greek alphabet in its development out of the Semitic alphabet is the consistent representation of vowels, a characteristic of the syllabic cuneiform system as well. Thus, Greek script was more appropriate than Aramaic for providing a full transliteration of the cuneiform (Oelsner 1986:243; 2002:16-17 n. 47). Despite the resort to Greek transliteration as a "pony," the cuneiform writing on these texts shows no signs of degradation, nor does any of the late cuneiform corpus, ${ }^{5}$ although

\footnotetext{
5 A unique tablet (Black 1997) excavated in a Hellenistic rubbish pit in Assyria (whence no other tablets are dated later than 600 b.c.) contains cuneiform numbers and cuneiform signs that look superficially correct but are anomalous and undecipherable.
} 


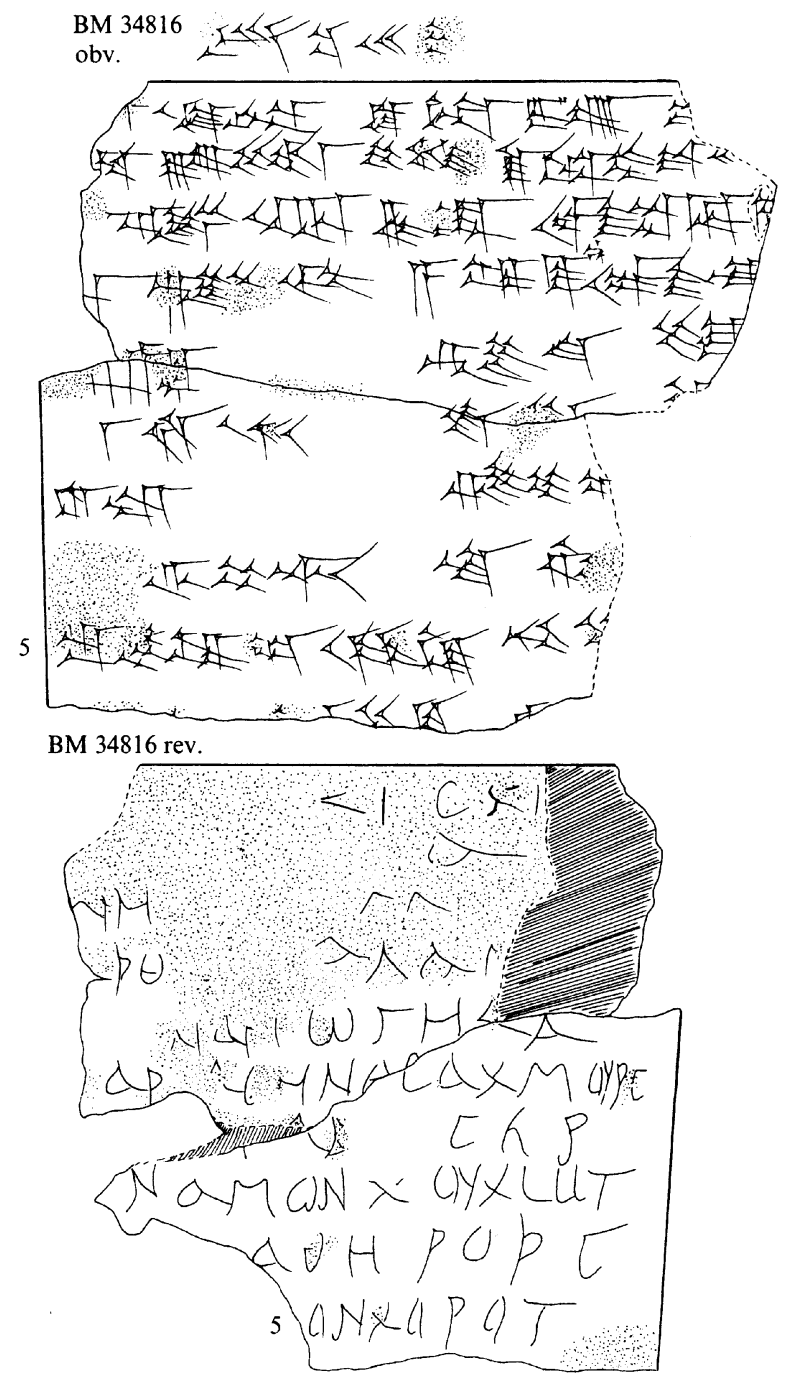

FIGURE 7. School tablet with bilingual cuneiform incantation excerpt on the obverse, Greek transliteration on the reverse (Geller 1997:no. 11).

"most of the latest Almanacs use unusual (and occasionally bizarre) terminology" (Sachs 1976:380).

It is doubtful that the writing of Sumerian and Akkadian in Greek transliteration had more than pedagogic significance. The musings of some scholars about significant quantities of Sumerian and Akkadian texts written on scrolls in Greek script (Oelsner 1986:473; Maul 1995:14-15; Geller 1997:48-49; 
Spek 1998:255) seem improbable, but the single reference in the colophon of an Akkadian cuneiform tablet to an Akkadian omen text written on a scroll (Oelsner 1986:244; Geller 1997:48) suggests that they are not impossible. What we have in the Graeco-Babyloniaca might be comparable to the dozen or so traditional Egyptian texts transliterated into a modified Greek script that is now termed Old Coptic (see p. 14; Emmel 1992; cf. Maul 1995:14), but there is nothing here that compares with the development of the thriving Coptic literary tradition that accompanied the Christianization of Egypt (Orlandi 1991).

Cuneiform writing and learning in the Sumerian and Akkadian languages seem to have declined gradually over the period of about half a millennium, ending in the second century of our era. Even if some of the decrease in the number of tablets could be explained by an increased use of perishable waxcovered writing boards (Oelsner 2002:15), in its final centuries, cuneiform was confined to the officials and scholars of the remaining temple communities where ancient Mesopotamian traditions were maintained. Our sources do not allow us to describe the processes of script obsolescence and extinction (see Rempel and Yoffee 1999 for the obsolescence of Mesopotamian culture in general). Lacking any evidence for the persecution or destruction of the cuneiform script community, we can only imagine that there were fewer and fewer students who studied cuneiform, until finally there were none and the script community died with its last members. The ancient Mesopotamian learning alluded to in sources later than the second century a.d. (Geller 1997; 2000; Dalley 1998) could well derive from pagan Aramaic literature (Salvesen 1998), written on perishable materials that have hardly survived at all.

MAYAN GLYPHS ${ }^{6}$

Mayan hieroglyphs or "glyphs" are the most elaborate form of script developed in the Pre-Columbian world. They were used from about a.d. 1 until early in the period of colonial rule (see below), and consisted of logographic, syllabic, and perhaps morphosyllabic elements whose decipherment continues, with notable progress in the last twenty years (Coe 1999). Most glyphs now have full phonic readings or at least semantic constraints that give us general ideas about their meaning. Glyphs were part of a much larger inventory of Mesoamerican writing systems. To understand that inventory it is useful to draw a distinction between "open" and "closed" writing systems (Houston 1994b). Such terms evoke a polarity suggested by Eric Wolf for types of peasant societies, "open" connoting constant interaction with other societies, "closed" a condition of pronounced autonomy and isolation (1955:462; compare Wolf 1986:326; Monaghan 1995:61). There is some advantage to stressing properties that transcend

\footnotetext{
${ }^{6}$ By a somewhat awkward scholarly convention, "Maya" ordinarily refers to a people or a region, "Mayan" to language and script.
} 
local conditions and those that accentuate them. Thus, while an "open" writing system serves the needs of diverse cultures and languages, a "closed" one implicates a particular culture or language.

In accommodating many different tongues, cuneiform tends toward an “open" system (Civil 1984; Cooper 2000:64-70). Egyptian and Mayan glyphs are far more "closed," and, in the Maya case, exceptionally clumsy in recording other languages. The lone Maya examples of such "foreign" or non-Mayan spellings are late, occurring in the Dresden codex and involving phonologically mangled deity names taken from Nahuatl, a dominant language of the Postclassic period (Taube and Bade 1991). Even in their pictorial imagery, the Maya rigorously delimited and encysted such foreign elements, marking them as out of the ordinary.

Mexican "pictography," rooted in western Mesoamerica, employs rebus in local languages, but its conventions and ancillary pictorial clues permit comprehension by speakers of assorted languages in many different regions (Boone 2000:239). Space within the Mexican screenfold books corresponds to space through which figures move, hence the frequent use of footprints to signal directional movement, as well as the tendency of Mexican pictorials to function as cartographic histories and delimitations of territory (Boone 2000:7782). Scripts in eastern Mesoamerica, especially Isthmian and Mayan, tend to be "closed" because of their firm bonding to certain languages, probably Ch'olti' an for Mayan glyphs (Houston et al. 2000), but with unclear linguistic affiliation for the undeciphered Isthmian (cf. proposals by Kaufman and Justeson 2001; see Houston 2000:130-31). The regional concentrations of open and closed writing point to different lines of descent from a precursor, probably a late Middle Formative (ca. 500 B.c.) system of image-making and graphic encoding of names. This system eventually fused with a separate system of numbering and calendrical notation (Houston 2001b); among the Maya this long survived the use of script per se. More than likely, the "open" tradition came into its own with the prestigious, pan-ethnic polity linked to the early first-millennium a.d. metropolis of Teotihuacan. Overlooked until recently, its writing highlighted the emblematic, bounded integrity of single signs over the stringing of signs into texts (Taube 2000). The sole exceptions to this pattern are the Teotihuacano texts found in the Maya region, including a mirror back that most likely comes from coastal Guatemala and linear inscriptions from the Cerro Bernal region of Chiapas, all dating to the middle Classic period (Taube 2000:34-43). These may have been influenced by the fuller texts and more "closed" style of Mayan writing, just as the Postclassic Mayan glyphs, aside from those in codices, show the pervasive influence of open pictography on what had been a profoundly closed system.

The majority of Mayan texts date to the Classic period, with the largest number attributable to the Late Classic (ca. a.d. 550-800). Most appear to have recorded a prestige language, Classic Ch'olti' an, that preserved archaic features 
long after their disappearance in speech (Houston et al. 2000). In the Terminal Classic period (ca. A.D. 800-900), the number of texts drops rapidly, to the extent that script obsolescence takes place in many areas that had once been literate, in an internal process of degradation many centuries before the Spanish conquest. The eighth-century A.D. Mayan script communities began to break apart. Their texts affect pronounced regionalisms: from A.D. 750 on, parts of Yucatan and Campeche show a high degree of grapholectal idiosyncrasy. Terminal Classic inscriptions from this area are also heterogeneous, with legible texts alongside those that veer close to pseudo-glyphs, signs that vaguely resemble glyphs, or real glyphs ordered into meaningless sequences. ${ }^{7}$ These pseudo-glyphs are an innovation of the Late Classic period and consist of spurious texts of real or impressionistic signs that sometimes occur on pottery. The difference between such marks and texts at sites like Yaxhom, in Yucatan (Fig. 8; e.g., Dunning 1992: figs. II-10, II-13, II-77), is that the latter correspond more to the work of "rememberers." There is no target script to emulate, no other option than to evoke a system that has passed from understanding. Another example of heterogeneity, neo-glyphs (some perhaps non-Mayan), and irregular word order is Monument 9 from López Mateos, in the heavily Maya state of Chiapas but very close to the non-Maya state of Oaxaca (Navarrete et al. 1993: fig. 30). The fluid and complex ethnicities of the region are reflected in an earlier text, Monument 10, that is fully Late Classic Maya in style (Navarrete et al. 1993: fig. 31).

Mayan writing also experiences a simplification and reduction of its signary. One of the latest known texts at Tonina, in Chiapas (Yadeun 1993:84-85), dates to a.d. 11 February 904, Julian (Fig. 9). At this site and others, such as Calakmul, in Campeche (Ruppert and Denison 1943: pl. 50b), late texts are nearly illegible because of the sloppy, irregular execution of glyphs. Varieties of suffix (e.g., T128 > T130), or even so-called "main signs," or larger glyphs (T544 > T281), melt into indistinguishable forms. The slack system of proportion in accompanying figures and iconography parallels a collapse in broadly understandable codifications of signs. However, such texts do preserve a relatively clear syntax of verb-object-subject, unlike the roughly contemporary texts at Seibal, Guatemala, where verbs drop out (Stela 3) and glyph blocks equate to single signs (Stela 13), an archaic pattern not seen consistently since the early years of Maya writing. Chronological moorings loosen, leaving the present-day viewer uncertain about the dates of particular monuments (Graham 1996:17, 37). Few public monuments of earlier periods would have shown so little concern for chronology. Moreover, the basic organizational instrument of earlier scribes was the "glyph block," a square unit that in archaic texts corresponded

${ }^{7}$ Mold-made Mayan texts, although legible, occur preponderantly in areas without other evidence of readable inscriptions, as in modern-day El Salvador and the Alta Verapaz, Guatemala (e.g., Schmidt et al. 1998: \#453); in such places one suspects a low rate of literacy. 


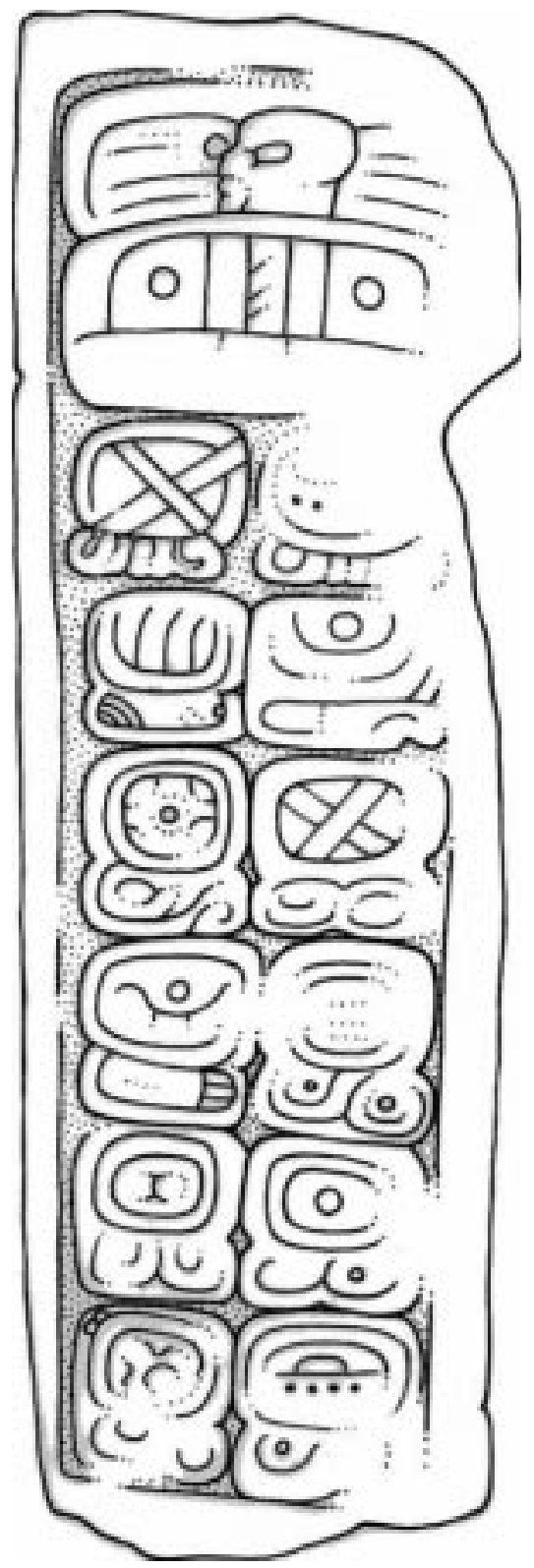

FIGURE 8. Terminal Classic pseudo-glyphs from Yaxhom, Yucatan (after photographs courtesy of Nicholas Dunning). 


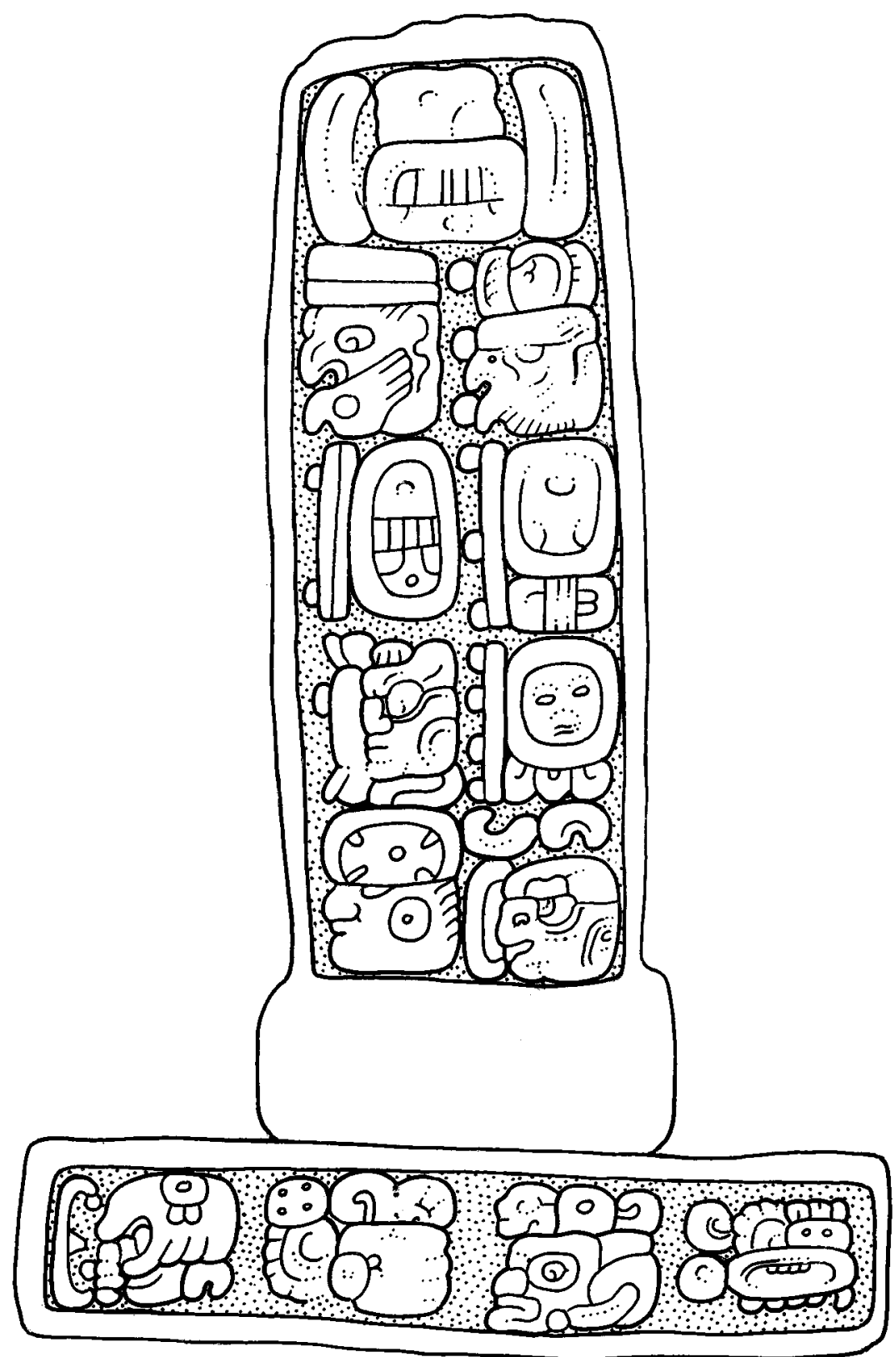

FIGURE 9. Terminal Classic stela of coarse sandstone, Tonina, Chiapas (after Yadeun [1993: 84-85]). 
to individual glyphs and in later, Classic texts roughly coincided with morphemic clusters. By the time of Terminal Classic texts at Chichen Itza, Yucatan, glyph blocks in some inscriptions had lost this morphemic clustering; some attached particles (or clitics) shifted into adjacent blocks away from the terms they qualified.

In a sense, the memory load has shifted strongly from the glyphs to the reader's mind. At Seibal, these developments probably occurred during two generations at most before the final cessation of writing, as part of a more general collapse of Maya society in the southern Lowlands of the Yucatan peninsula. The heterogeneous text styles at the site suggest the presence of several "tips" or destructive episodes before literacy dissolves entirely. Other sites present evidence not of gradual decline but of radical or complete and abrupt obsolescence. Piedras Negras, for example, goes within a few years from some of the most ambitious compositions, such as Stela 12 (A.D. 795), to a complete absence of texts. The poorly understood Isthmian writing of ca. 700 years before also disappears without evidence of gradual obsolescence.

As script communities fragment, and their terminal or final writers diminish in number, the sum of glyphic knowledge, the mutual supervision that judges and encourages standards, must also wither, dropping to a danger level below which the script will disappear. In no instance of internal obsolescence-that is, from the pre-Colonial period - is there any sign of stigmatization or diminished prestige of the Maya script, or of dominant scripts attracting new attention. For reasons of general social collapse, the script communities simply could not reproduce themselves. The destruction and disintegration of court culture that characterized the Maya region at the end of the Classic period would have removed the "ecological" setting (in the cultural and social sense specified earlier) in which scribes existed and thrived (Inomata and Stiver 1998). These conditions point to a further feature: as long as some scribes survived and transmitted their knowledge, and interest in recording matters relevant to Maya belief endured, script could adjust to and persist in the reconstituted societies of the Postclassic period.

The latest writing of the Maya-that of the Postclassic (ca. A.D. 900-1540) and Colonial periods (ca. A.D. 1540-1820)—remains notoriously difficult to study. With only a handful of exceptions, script shifted to an exclusively painted format, and few such paintings are known. This emphasis on a single medium recalls the focus on carving or incision at Classic Maya cities such as Piedras Negras, Guatemala. Four codices represent the largest body of writing from the Postclassic, but these are of controversial date and in two cases (the Madrid and Grolier) display a striking lapse of textual clarity and scribal competence. The Grolier in particular is largely an "open" document in which identity and action are communicated by iconography rather than glyphs, probably as a result of forceful influence from Mexican pictography (Coe 1973: pl. 87). 
The suggestion that the Madrid comes from the Colonial period is intriguing and buttressed by what appears to be Spanish paper in the fabric of the codex (Coe and Kerr 1998:181). Should this dating be correct, one would expect, as with Mexican pictorials, at least a hint of Colonial influence or the depiction of Colonial items. For example, all artifacts pictured on its fig-bark pages are decisively Pre-Columbian in form (Graff 1997). Until AMS-radiocarbon dating of the codex becomes possible-unlikely given its great value and zealous curation-the general consensus must be that it is Pre-Columbian.

Other Postclassic texts - many poorly fixed in absolute chronology — show writing that seems much simplified from its Classic apogee. A text from the Las Pinturas temple at Coba, probably of the Middle Postclassic, features deity names and offerings, presumably to be given to the gods, but little transparent syntax or verb morphology (Houston 1989: fig. 19). The mere juxtaposition of elements must have triggered an appropriate ritual response in the reader-a list of instructions for use of the temple, as it were-since the texts provide little other explanation. Other painted texts from this area show day signs floating in iconographic scenes, much like examples from Mexican pictography (Taube 1989: figs. 4, 5). From Chichen Itza, Yucatan, come Late Postclassic bowls with numbers, but no day signs (Ball and Ladd 1992: fig. 7.55). Mayapan, relatively close by, has numerically notated day signs adorning the backs of cosmic turtles (Taube 1988). A well-known but highly unusual stela from the same site has thirty-six blank blocks, presumed to be painted but without secure evidence of this; indistinct vestiges of carving may show that the texts were faintly carved (Martin and Grube 2000:228). Painted medallions from inner chambers of a building at Dzibilchaltun, Yucatan, probably from the Late Postclassic, are instances of writing as process and performance, for they were periodically restuccoed and repainted (Andrews IV and Andrews V 1980:11217). Again, the texts contain day signs and iconographic elements, including a lunging animal, all with poor attention to the neat ordering of glyphs and images. Another example of numbers, arranged in a cosmic model of centrality, is in a cave near Tixkuytun, Yucatan, in a context of uncertain date (Stone 1995: pl. 4). A single deity name occurs on a ceramic plates from Mayapan, presumably in reference to the intended recipient of offerings placed on it (Smith 1975: fig. 40a). No other glyphs are known from pottery at this important and wellinvestigated site.

Glyphically, such paintings are limited in comparison to the few remaining codices. Dates, not dynasties, are the focus. Verbs and other staples of Classic Maya glyphic discourse drop by the wayside. As objects, the texts are even less autonomous than Classic period inscriptions. Imagery has come to play a disproportionate role, in a way that differs decidedly from the greater, reciprocal balance between image and glyph in the Dresden Codex or the heavily glyphic Paris codex. The Postclassic paintings from buildings and caves relate only 
to the calendar, a vastly reduced and semantically distinct system of notation. Although these dates and numbers are still graphic notations, they should not be confused with Maya writing with its supple, phonic capabilities. Only the few remaining codices tell of broader proficiency, and of glyphs that serve as linchpins of meaning rather than ancillary communications.

This attenuation and restricted literacy set the stage for the final obsolescence of Mayan script. The Spanish clerics who interested themselves in the writing had, with one notable exception, relatively little to say about its structure and content (Houston et al. 2001:25-44). They referred vaguely, and perhaps incorrectly, to laws, histories, ceremonies, astronomy, conjuring rites, "syllables," planting, hunting, and military cycles, all recorded in large numbers of books but read by few. Some clerics, probably the vast majority, encouraged the burning of books; others felt the calendars in particular were useful for agricultural reasons (Houston et al. 2001:40). The one person to observe more, far more, was Bishop Diego de Landa. The story of Landa's astonishing details and their connection to Maya decipherment has been told elsewhere (Coe 1999). What is significant here is the nature of the information he collected, probably in large part from a baptized Maya of noble lineage, Gaspar Antonio de Herrera Chi (ca. 1531-1610; Strecker and Artieda 1978; Karttunen 1994:84-114).

The usual interpretation of the misleading treatment of Mayan glyphs in Landa's Relación de las cosas de Yucatán is that the Bishop was being obtuse, insisting on a view of writing that accorded with his own occidental script: hence the glyphic expression, ma in k'ati, "I do not want" from his pained and frustrated informant. An alternative impression would be that the Chi did not himself employ the script with any great familiarity, and that his knowledge was deficient: it is known that he passed, fatherless, into Franciscan hands at the age of fifteen (Karttunen 1994:92). No earlier Maya scribe would have written the pronoun "I" as 'i-ni, but would have used instead the syllable ni, yet this portion of Landa's manuscript has been presumed to be a literate transcription of Maya by an indigenous user of the script. ${ }^{8}$ For all the great value of Landa's (and Chi's) data, some of syllables seem to devised ad hoc, as in xe, showing a person vomiting, and taken from Yukatek xeh, "vomit"; the b'e syllables surely had a different vowel, [i]. Moreover, in Houston's experience teaching in an American university, beginning students tend to write glyphs in a linear fashion, each rendered separately, according to a pattern directly influenced by alphabetic script. Until pressed, they avoid the tightly clustered glyph blocks employed by the Maya. So too with Landa's informant: he wrote ma-'i-ni-k'a-ti, not in Mayan blocks, but in a European ordering of disconnected elements. Since the Landa manuscript is a copy (the original is lost) the unusual ordering

${ }^{8}$ In Maya studies syllabic glyphs are shown in bold lower-case letters, logographs (word signs) in bold upper-case. 
could have been introduced later, but this explanation fails to accord with what appear to be otherwise careful transcriptions in the copy now in Madrid. All this evidence hints that Mayan script was not effectively communicated for long after the sixteenth century, and was already in disrepair and in discontinuity with past usage.

The disruption of priestly schools, the burning of codices - arguably the principal repository of glyphic exemplars - and, as on Rapa Nui, the death by disease of so many literates (cf. Fischer 1997:9; and García Bernal 1978; Lovell 1991) would have led, perhaps in a single generation, to the tip of Maya writing into final obsolescence. This was doubtless exacerbated by the esoteric nature of the archaic prestige language recorded in the script, which at the time could hardly have been spoken by many people. The death of such a restricted language, with few speakers and limited registers of use, would inflict corresponding damage on the script. What remained were day signs, twenty in total and easily memorized, and only one, that for "lord," ahau, surviving into the nineteenth century, fully equipped with European crown, cross, and sometimes bearded visage. By the late eighteenth century, the other day signs had already deteriorated into squiggles lacking all distinctive attributes (Fig. 10; Book of Chilam Balam of Chumayel, Coe 1973: pl. 88). The survival of glyphs in isolation has more a feel of "rememberers" than fullfledged users of a writing system. Here, a dominant script overwhelmed a subordinate one.

By the Colonial period, the glyphs that did survive suggest, not expansive glyphic literacy but secretive and selective preservation of a few signs: the books of Chilam Balam, in which the glyphs endured, were usually kept out of view. Indigenous languages were used for notarial and other documents at the local level in the exercise of partial self rule, political negotiation with the Spanish authorities, both secular and ecclesiastical, and, paradoxically, the consolidation and reinforcement of native identity. Since many of the first Maya users of the Roman alphabet were local elites, they probably lived for a generation in a biliterate environment, in which compelling forces caused individuals to replace one with the other. In this, the Mexican pictorials did far better, being used and-in the example of the eighteenth-century Techialoyan manuscripts in Nahuatl-forged for submission as legal evidence in Colonial courts (Boone 2000:245-46). Dynastic narratives and mapmaking were acceptable to the Spanish authorities; the amalgam of calendar, rite, and deities in late Mayan writing was not. Mexican pictorials, even those portions that are decidedly lexemic and linguistic, suggest that open writing tends to adapt readily to new scripts, going so far as to absorb features from them. Several authors have stressed the elaboration of phonetic elements and linear text in Mexican pictorials as postdating the Spanish conquest, presumably under influence from Roman script and new, more discursive modes of presentation (Dibble 1971:330- 


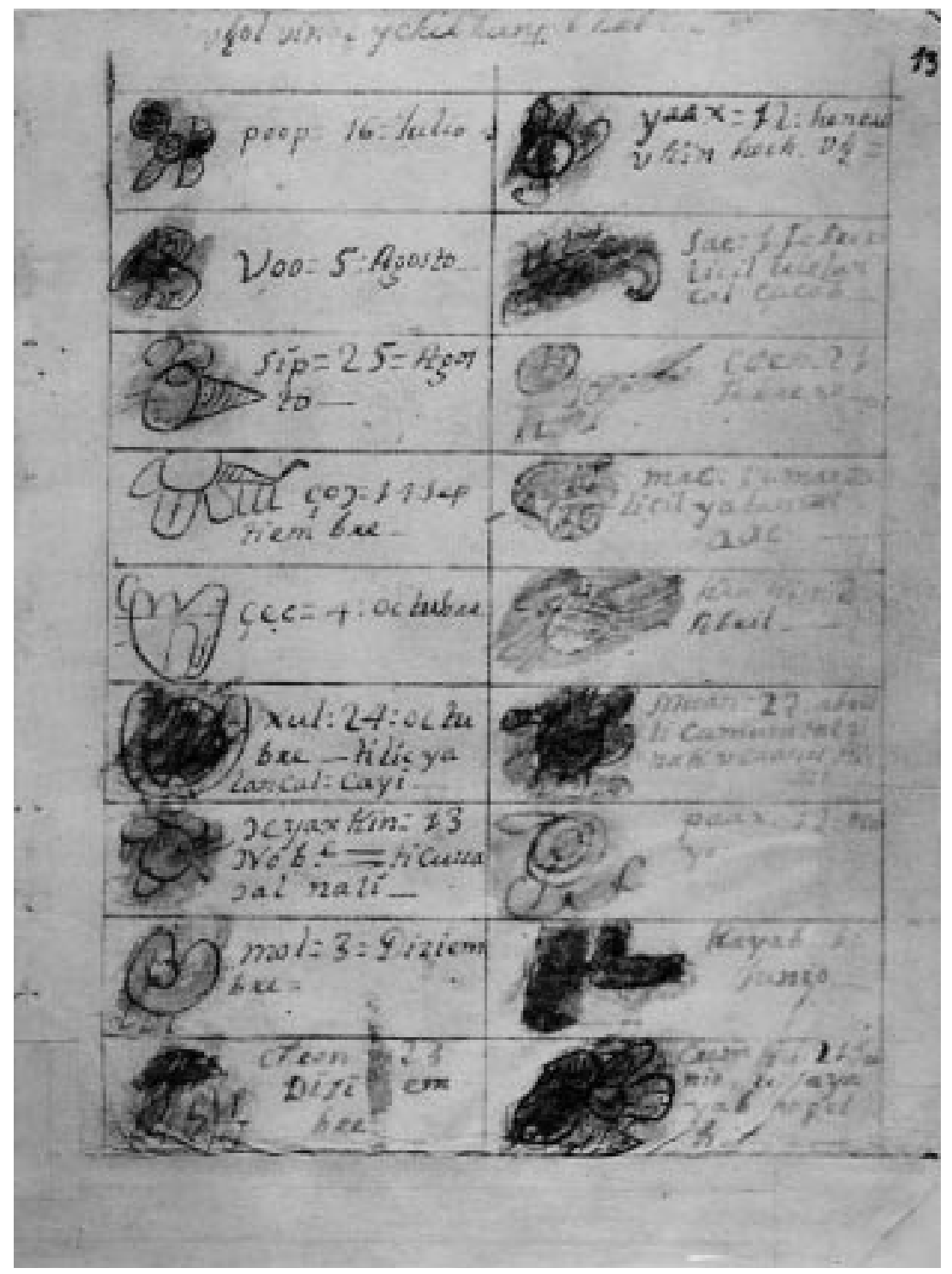

FIGURE 10. Page from the Colonial Book of Chilam Balam of Chumayel (Coe 1973: pl. 88). 
31; cf. Nicholson 1973:36). The elaborate, still enigmatic glyphic sequences in the Codex Xolotl, a sixteenth-century example from the region of Texcoco, Mexico, are a case in point. ${ }^{9}$

In sum, Terminal Classic writing experienced not one but many deaths, depending on site and region, as script communities fragmented and lost contact with one another. This is consistent with the variable and idiosyncratic nature of the Maya Collapse and the extinction of royal courts across the Maya Lowlands (Webster 2002:343-47). The evidence runs the gamut from rapid or radical obsolescence to gradual extinction, and, in final vestiges, to the pseudoglyphs of "rememberers." But a few centers must have preserved glyphic knowledge. By Postclassic times, the glyphs in their more elaborate form had become largely restricted to a single genre and medium, that of the screenfold manuscripts or "codices." The numbers of these books cannot be estimated. Allusions to thousands may be the exaggerations of clerical propagandists wishing to emphasize their triumphant destruction of indigenous belief and its instruments of propagation. In any case, their absolute number is less relevant than their comprehensive contrast with more public texts, a fuller code in the codices differing from a restricted code in more public settings. The Grolier hints that "open" Mexican pictography penetrated from those settings into the codical tradition. With the Conquest, the religious contents of the codices made them inherently obnoxious to the Spaniards, who destroyed most of the books perhaps within the third quarter of the sixteenth century. The obliteration of the prestige language that had come to be closely associated with script further undermined use of Mayan glyphs: with that destruction came the unraveling of the glyphic script community in favor of one emphasizing the roman alphabet.

9 There is a claim for the ghostly impress of Mayan glyphs in later, alphabetic writing of the Yucatan peninsula (Bricker 1989). According to this argument, a variety of spellings in the prophetic Books of Chilam Balam of Chumayel and Chan Kan reflect conventions that only make sense in terms of influence from a logosyllabic script-namely, Mayan writing. These features are thought to include consonant insertion ("a CVC root plus a VC grammatical suffix [recorded with] two CVC clusters" [Bricker 1989: 40]); vowel insertion (CVV records CV', CVh, CVy, or -VC [Bricker 1989: 43]); vowel deletion (C for CV syllables [Bricker 1989: 44], perhaps because Maya scribes learned letter values as syllables); and consonant deletion (dropping final consonants [Bricker 1989: 45]). The difficulty with this hypothesis is that the spellings do not conform to glyphic usage. When scribes working with glyphs wished to write a VC "grammatical suffix" they did so with -VC forms, not CVC (i.e., -IL and other morphosyllables). The glyphic examples cited by Bricker are different expressions and do not belong to a single, contrastive set (i.e., not ba-te $\sim$ bat-te, as she asserts, but B'AAH-TE' $\neq$ KALOOM-TE'. Bricker's orthography is hers, ours uses newer Mayanist conventions). The presumed "vowel insertion" involves misconstrued examples (i.e., not u-te-e, but U-TE-'e, thus /te'/), as do the examples of dropped final consonants (i.e., not k'a but K'AHK'k'a, and kuk-mo $\neq$ k'u-yu/?-ki-AJAW-mo-' $\mathbf{o}$ ). In other words, the conventions in the Colonial documents do not match any attested conventions of glyphic spelling. The glyphs cited in favor of the hypothesis are, with few exceptions, misinterpreted. In fairness to Bricker, her piece was written well before recent revisions in glyphic knowledge. If her suggestion is excluded, this supports the probability that glyphic "consciousness" failed to influence Mayan literacy into the Colonial period. Moreover, one of the lone examples of non-calendrical glyphic writing from the late seventeenth century — a supposed name glyph—is now known to be a forgery (Prem 1999). 
Claims for later glyphic literacy, in the sense of logosyllabic script rather than remembered day signs, are unconfirmed and unlikely.

\section{DISCUSSION}

This comparison of three important script traditions-Egyptian, cuneiform, and Mayan in its Mesoamerican setting-highlights similarities and differences in their patterns of obsolescence. All involved, to some extent, sociolinguistic, "spheres-of-exchange," and demographic assaults. All experienced a dramatic reduction in function and, perhaps, content: the latest datable cuneiform text pertains to astronomy; Egyptian hieroglyphic became "celebratory" and temple-oriented, demotic equally tethered to the values of a civilization neglected and latterly under cultural assault; and Mayan glyphs, wholly unlike the "open" pictography of Mexico, became highly restricted in function and use, with a near-total attenuation of public functions. Mayan glyphs were identified, at least in their non-calendrical portion, with a religious system that was noxious to their conquerors; similarly, Egyptian writing was closely linked to traditional religion that increasingly lost state sponsorship and, like cuneiform, a native elite that would value its messages. In all cases scripts were tenacious until their script communities became unable to sustain the investment involved in transmitting such systems across generations or found it desirable to discontinue doing so. The disappearance of Hieroglyphic Luwian in mid-first-millennium b.c. Syria must be seen as linked to the demise of local dynasties in the face of Assyrian expansion (Hawkins 1995), rather as Cypriote disappeared with the religious cult that nourished it (see above; Pope 1999:145), Kharosthī faded with the extinction of the Kusāna empire, and the Mormon Deseret alphabet declined with the demise of its chief patron, Brigham Young (Watt 1994). All were endangered by their specialized functions, linkages with a limited sphere of patrons, and political ties. Once a niche dissolved-the need to record astronomy, particular kinds of calendrical notations, and invocations of dwindling gods - a script community would find its investment without clear dividend. In some respects, this pattern closely accords with a crucial principle of language change, proposed by Kurylowicz (1966:164) as his Second Law of Analogy and refined by Robertson (n.d.): "[i]n a linguistic paradigm, the form of a less marked category tends to impose itself on neighboring, more marked categories." In like manner, a script with general functions tends to displace a script with specific ones, in a "sphere-of-exchange" shift. In all cases, it seems likely that dying scripts had such restricted functions.

All these scripts had as alternatives "target" writing systems, often connected to dominant groups and languages-Aramaic and Greek in Mesopotamia, Greek in Egypt, Spanish among the Maya - that did not have problematic connections to languages and high cultures of diminished interest. In this sense, their obsolescence, in a context of biliteracy or triliteracy, is utterly different from instances of script collapse in which no target script was available: Indus 
script did not find a local replacement for over a millennium, and in Crete and mainland Greece the demise of Linear B was followed by illiteracy for several centuries (Bennett 1991). It is telling that their obsolescence was "radical." Most examples of Linear B were only preserved fortuitously by the burning of palace complexes with their archives (Chadwick 1976:18). By the time of their abandonment, Egyptian, cuneiform, and Mayan must have accrued sufficient negative prestige and stigma to discourage further use. The reduced, highly specialized functions made this disuse relatively painless for most people or, to put this another way, made it quite painful for just a few committed people-a "tip" or negative influence that might have amounted to little more than a nudge.

The tip into obsolescence varied in its social or cultural motivation. For Egypt, Mesopotamia, and the Maya, indigenous elites were closely associated with weakening scripts. In Egypt, the crises of the third-century a.d. Roman empire undermined official sponsorship of temple-based script communities that used Egyptian writing; what persisted in their place were Greek-based institutions and later the Coptic church. Among the Maya, native elites who might ordinarily promote and employ glyphs were physically exterminated or co-opted into reconfigured societies that prized Roman script. This appears also to have been true of Rongorongo on Rapa Nui, whose population was devastated by Peruvian labor gangs and smallpox (Fischer 1997:20). As argued above, the claims for sustained, covert, and highly competent use of Maya glyphs are less credible than a scenario of rapid decay in the sixteenth century. Bishop de Landa's informant's knowledge was already deformed by Spanish practices. The few glyphs in continued use were the domain of "rememberers" wielding a progressively more schematic form of the calendrical signary. The comparative study of pseudo-writing, including those mentioned here from Egypt and the Maya, has not yet been attempted in any systematic fashion (but see Cardona 1981); supposed "magical" functions are only part of the story in what must have been a complex admixture of inept copying, fakery, and deliberate eschewal of literate expression. Cuneiform, by contrast, ceased to play a monumental or decorative role many centuries before its demise, so there was little motivation to produce pseudo-cuneiform or debased signs.

A significant difference between the scripts covered here is that Egyptian was a living language in the period when its scripts ceased to be used, even if the written form was a long way from the spoken. Cuneiform, by contrast, wrote languages that had long ceased to be spoken, as may have been equally true for the archaic language recorded in the Postclassic Maya codices (Houston et al. 2000). In this sense they could be compared to the position of classical Greek in the Islamic Middle Ages. In the period after the scripts disappeared, Coptic continued to record Egyptian, but other scripts did not take up the languages of cuneiform and Mayan writing. Thus, different civilizational and linguistic contexts affected profoundly the pattern of script loss.

For the Mayan script there is evidence of both simplification and defective- 
ness, in the vastly complicated multiple collapses among Terminal Classic dynastic societies. At some cities the script declined rapidly, in a "radical" manner, in other cities by incremental decay into pseudo-glyphs, a pattern that reflected the break-up of supra-regional script communities into highly localized ones. The patchwork decline of Egyptian hieroglyphic and demotic, with restricted examples of robust survivals, suggests a pattern of surviving, but in the end isolated script communities: the smaller their size, the smaller their chances of securing cross-generational transmission and the more limited the range of what they could write, until it became restricted to date formulas and names, albeit competently inscribed. The example of cuneiform is both clearer and more opaque: the latest examples are proficient if bizarre in terminology, yet difficult to situate within any detailed image of the script community. There may be a statistical decline in the frequency of cuneiform texts, but, with one unclear exception (see n. 5), there is no perceptible decay of writing into the scribbles of rememberers.

When a language disappears, it must be replaced by another. Language replacement is a cultural, often political and sociolinguistic, matter, but script disappearance or replacement is more exclusively cultural, and for the pre-modern world - with its limited literacy and great investment in symbolic modes of communication and commemoration-mostly high-cultural. It is symptomatic of this cultural salience that the last uses of our three scripts were for purposes that were deeply embedded in their civilizations. In the cases of Egyptian and cuneiform, these continued written traditions that embodied ancient learning. In Egypt, the pictorial decoration in the temples, where most of the latest writing is found, was systematically mutilated in early Christian times. This testifies to the power of those cultural symbols, further reinforced by the frequent siting of churches in the same spaces. The writing itself was not attacked, presumably in part because few could read it. While Maya glyphs rarely show evidence of damnatio memoriae - the deliberate erasure of names or text (Keppie 1991:22) - they do display mutilation of eyes and noses, for which there are two possible explanations, neither mutually exclusive: (1) the defacements neutralized or "killed" animated or vital images (Houston and Stuart 1998: 88); or (2) the mutilations reflected a time - the Maya Collapse - when faces could be recognized and dishonored but not glyphic content, which had passed into unintelligibility. Few Maya stelae have escaped this kind of damage.

A crucial feature of Egyptian and Mayan script obsolescence may be the disintegration of linked pictorial traditions. Maya iconography, for example, declines rapidly in the early Colonial period, when it was replaced by a passion for Hapsburg eagles (Stone 1995: fig. 4-73) and by crude pictographs that had virtually no connection to the conventions of high culture. This ligament to other graphic forms of communication exemplifies how the margins of this study open out onto unexplored terrain, including script obsolescences from Meroitic to Isthmian that are not covered in this survey, as well as disappearing artistic 
traditions that are replaced by radically different ones. Sampling and other problems will make some of these narratives of decline in script and picture difficult to reconstruct. But the comparative impulse will eventually elucidate, to common satisfaction, why they, along with Egyptian, cuneiform, and Mayan, found it impossible to endure.

\section{REFERENCES}

Andersen, R. W. 1982. "Determining the Linguistic Attributes of Language Attrition." In R. D. Lambert and B. F. Freed, eds., The Loss of Language Skills. Rowley: Newbury House, $83-118$.

Andrews, E. W., IV, and E. W. Andrews, V. 1980. Excavations at Dzibilchaltun, Yucatan, Mexico. Middle American Research Institute, Publication 48. New Orleans: Tulane University.

Bagnall, R. 1993. Egypt in Late Antiquity. Princeton: Princeton University Press.

Baines, J. 1983. "Literacy and Ancient Egyptian Society." Man 18:572-99. . 1989. "Communication and Display: The Integration of Early Egyptian Art and Writing." Antiquity 63:471-82.

— 2003 (in press). "The Earliest Egyptian Writing: Development, Context, Purpose.” In S. D. Houston, ed., The First Writing. Cambridge: Cambridge University Press.

Baines, J., K. Donker van Heel, and H.-W. Fischer-Elfert 1998. "Abnormal Hieratic in Oxford: Two New Papyri.” Journal of Egyptian Archaeology 84:234-36.

Ball, J. W., and J. M. Ladd. 1992. "Ceramics." In C. C. Coggins, ed., Artifacts from the Cenote of Sacrifice, Chichen Itza, Yucatan. Memoirs of the Peabody Museum of Archaeology and Ethnology, Harvard University, vol. 10, no. 3. Cambridge, Mass.

Basso, K. H., and N. Anderson 1975. A Western Apache Writing System. Lisse: Peter de Ridder Press.

Bazemore, G. B. 1994. "Syllabary and Alphabet in Cyprus: Evidence for the Role of Script in Ancient Society." American Journal of Archaeology 98:290.

Beinlich, H. 1991. Das Buch vom Fayum: zum religiösen Eigenverständnis einer ägyptischen Landschaft. Ägyptologische Abhandlungen 51. 2 vols. Wiesbaden: Otto Harrassowitz.

Bennett, E. L. 1991. "The End of the Mycenaean Script: The Case of the Missing Heirs." In D. Musti, A. Sacconi, L. Rocchetti, M. Rocchi, E. Scafa, L. Sportiello, and M. E. Giannotta, eds., La transizione dal Miceneo all'alto archaismo: dal palazzo alla città. Atti del convegno internazionale, Roma, 14-19 marzo 1988. Rome: Istituto per gli Studi Micenei ed Egeo-Anatolici, Consiglio Nazionale delle Ricerche, 563-70.

Black J. A. 1997. "Hellenistic Cuneiform Writing from Assyria: The Tablet from Tell Fisna." Al-Rāfidān 18:229-38.

Boone, E. H. 2000. Stories in Red and Black: Pictorial Histories of the Aztecs and Mixtecs. Austin: University of Texas Press.

Bricker, V. R. 1989. "The Last Gasp of Maya Hieroglyphic Writing in the Books of Chilam Balam of Chumayel and Chan Kan." In W. F. Hanks and D. S. Rice, eds., Word and Image in Maya Culture: Explorations in Language, Writing, and Representation. Salt Lake City: University of Utah Press, 39-50.

Campbell, G. 1997. Handbook of Scripts and Alphabets. London: Routledge.

Campbell, L., and M. C. Muntzel. 1989. "The Structural Consequences of Language Death.” In N. C. Dorian, ed., Investigating Obsolescence: Studies in Language Contraction and Death. Cambridge: Cambridge University Press, 181-96.

Cardona, G. 1981. Antropologia della scrittura. Turin: Loescher. 
Chadwick, J. 1976. The Mycenaean World. Cambridge: Cambridge University Press.

Civil, M. 1984. "Bilingualism in Logographically Written Languages: Sumerian in Ebla.” In L. Cagni, ed., Il bilinguismo a Ebla. Naples: Dipartimento di Studi Asiatici, Istituto Universitario Orientale, 75-97.

Clackson, S. J. 2000. Coptic and Greek Texts Relating to the Hermopolite Monastery of Apa Apollo. Griffith Institute Monographs. Oxford: Griffith Institute.

Clarysse, W., G. van der Veken, and S. P. Vleeming 1983. The Eponymous Priests of Ptolemaic Egypt: Chronological Lists of the Priests of Alexandria and Ptolemais with a Study of the Demotic Transcriptions of Their Names. Papyrologica Lugduno-Batava 24. Leiden: Brill.

Clement of Alexandria 1981. Les Stromates: Stromate V. Sources Chrétiennes 278, 279. 2 vols. Paris: Editions du Cerf.

Coe, M. D. 1973. The Maya Scribe and His World. New York: Grolier Club.

. 1999. Breaking the Maya Code. Rev. ed. London: Thames and Hudson.

Coe, M. D. and J. Kerr. 1998. The Art of the Maya Scribe. New York: Harry Abrams.

Collombert, P. 2000. "Religion égyptienne et culture grecque: l'exemple de $\Delta 10 \sigma-$

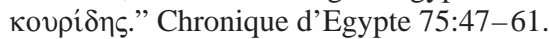

Coningham, R.A.F., F. R. Allchin, C. M. Batt, and D. Lucy. 1996. "Passage to India? Anuradhapura and the Early Use of the Brahmi Script." Cambridge Archaeological Journal 6: 73-97.

Cooper, J. 1996. "Sumerian and Akkadian." In P. T. Daniels and W. Bright, ed., The World's Writing Systems. Oxford: Oxford University Press, 37-57. . 1999. "Sumerian and Semitic Writing in Most Ancient Syro-Mesopotamia." In K. Van Lerberghe and G. Voet, eds., Languages and Cultures in Contact. Proceedings of the 42nd Rencontre Assyriologique Internationale. Leuven: Peeters, 61-77.

_ 2003 (in press). "Babylonian Beginnings: The Origin of the Cuneiform Writing System in Comparative Perspective." In S. D. Houston, ed., The First Writing. Cambridge: Cambridge University Press.

Cribiore, R. 1996. Writing, Teachers, and Students in Graeco-Roman Egypt. American Studies in Papyrology 36. Atlanta, Ga.: Scholars' Press.

Crystal, D. 2000. Language Death. Cambridge: Cambridge University Press.

Dalby, D. 1968. "The Indigenous Scripts of West Africa and Surinam: Their Inspiration and Design." African Language Studies 9:156-97.

Dalley, S., ed. 1998. The Legacy of Mesopotamia. Oxford: Oxford University Press.

Daniels, P. T. 1990. "Fundamentals of Grammatology." Journal of the American Oriental Society 110, 3: 727-31.

Daniels, P. and W. Bright. 1996. The World's Writing Systems. Oxford: Oxford University Press.

Davies, W. V. 1987. Reading the Past: Egyptian Hieroglyphs. London: British Museum Press.

Depauw, Mark 1997. A Companion to Demotic Studies. Papyrologica Bruxellensia 28. Brussels: Fondation Egyptologique Reine Elisabeth.

Derchain, P. 1987. Le dernier obélisque. Brussels: Fondation Egyptologique Reine Elisabeth.

Dibble, C. E. 1971. "Writing in Central Mexico.” In G. F. Ekholm and I. Bernal, eds., Handbook of Middle American Indians, Volume 10: Archaeology of Northern Mesoamerican, Part One. Austin: University of Texas Press, 322-32.

Dixon, R.M.W. 1997. The Rise and Fall of Languages. Cambridge: Cambridge University Press.

Dorian, N. C. 1981. Language Death: The Life Cycle of a Scottish Gaelic Dialect. Philadelphia: University of Pennsylvania Press. 
1998. "Western Language Ideologies and Small-language Prospects.” In L. A. Grenoble and L. J. Whaley, eds., Endangered Languages: Language Loss and Community Response. Cambridge: Cambridge University Press, 3-21.

Doty, L. T. 1977. Cuneiform Archives from Hellenistic Uruk. Ph.D. dissertation, Yale University.

Dreyer, G., U. Hartung, and F. Pumpenmeier 1998. Umm el-Qaab I: Das prädynastische Königsgrab U-j und seine frühen Schriftzeugnisse. Deutsches Archäologisches Institut, Abteilung Kairo, Archäologische Veröffentlichungen 86. Mainz: Philipp von Zabern.

Dümichen, J. 1877. Baugeschichte des Denderatempels und Beschreibung der einzelnen Theile des Bauwerkes nach den an seinen Mauern befindlichen Inschriften. Strasbourg: K. J. Trübner.

Dunning, N. P. 1992. Lords of the Hills: Ancient Maya Settlement in the Puuc Region, Yucatán, Mexico. Madison, Wis.: Prehistory Press.

Eckholm, E. 2000. "A Dying Culture, as Seen through Aging Eyes." The New York Times, Wed. 5 Jan.

Edwards, J. 1992. "Sociopolitical Aspects of Language Maintenance and Loss: Towards a Typology of Minority Language Situations.” In W. Fase, K. Jaspaert, and S. Kroon, eds., Maintenance and Loss of Minority Languages. Amsterdam: John Benjamins, $37-54$.

Eisenstadt, S. N. 1988. "Beyond Collapse.” In N. Yoffee and G. L. Cowgill, eds., The Collapse of Ancient States and Civilizations. Tucson: University of Arizona Press, 236-43.

Emmel, S. 1992. “Coptic.” In D. N. Freedman, ed., The Anchor Bible Dictionary. New York: Doubleday, 4:180-88.

Englund, R. 1998. “Texts from the Late Uruk Period.” In J. Bauer, R. Englund, and M. Krebernik, eds., Mesopotamien. Späturuk-Zeit und Frühdynastischer Zeit. Orbis Biblicus et Orientalis 160/1. Freiburg/Göttingen: Universitätsverlag/Vandenhoeck \& Ruprecht, 15-233.

- 2003 (in press). "The State of Decipherment of Proto-Elamite.” In S. D. Houston, ed., The First Writing. Cambridge: Cambridge University Press.

Fischer, S. R. 1997. Rongorongo, the Easter Island Script: History, Traditions, Texts. Oxford: Clarendon Press.

Frandsen, P. J., ed. 1991. Demotic Texts from the Collection. The Carlsberg Papyri 1. CNI Publications 15. Copenhagen: Museum Tusculanum Press.

Frandsen, P. J., and K. Ryholt, eds. 2000. A Miscellany of Demotic Texts and Studies. The Carlsberg Papyri 3. CNI Publications 22. Copenhagen: Museum Tusculanum Press.

Frankfurter, D. T. 1998. Religion in Roman Egypt: Assimilation and Resistance. Princeton: Princeton University Press.

García Bernal, M. Cristina. 1978. Yucatán: Población y encomienda bajo los Austrias. Sevilla: Escuela de Estudios Hispano-Americanos.

Garzon, S. R. McK. Brown, J. B. Richards, and Wuqu' Ajpub' (A. Simón) 1998. The Life of Our Language: Kaqchikel Maya Maintenance, Shift, and Revitalization. Austin: University of Texas Press.

Gaur, A. 1992. A History of Writing. New York: Cross River Press.

Gelb, I. J. 1963. A Study of Writing. 2d ed. Chicago: University of Chicago Press.

Geller, M. 1997. "The Last Wedge." Zeitschrift für Assyriologie 87:43-95.

- 2000. "The Survival of Babylonian Wissenschaft in Later Tradition.” In S. Aro and R. Whiting, eds., The Heirs of Assyria. Helsinki: Neo-Assyrian Text Corpus Project, $1-7$. 
Gesche, P. 2000. Schulunterricht in Babylonien im ersten Jahrtausend v. Chr. Alter Orient und Altes Testament 275. Münster: Ugarit Verlag.

Goody, J., ed. 1968. Literacy in Traditional Societies. Cambridge: Cambridge University Press.

Goody, J. and I. Watt. 1963. "The Consequences of Literacy." Comparative Studies in Society and History 5, 3:304-45.

Graff, D. H. 1997. "Dating a Section of the Madrid Codex: Astronomical and Iconographic Evidence.” In V. R. Bricker and G. Vail, eds., Papers on the Madrid Codex. Middle American Research Institute Publication 64. New Orleans: Tulane University, 147-67.

Gragg, G. 1996. “Other Languages.” In P. T. Daniels and W. Bright, eds., The World's Writing Systems. Oxford: Oxford University Press, 58-71.

Graham, I. 1996. Corpus of Maya Hieroglyphic Inscriptions, Volume 7, Part 1: Seibal. Cambridge, Mass.: Peabody Museum of Archaeology and Ethnology, Harvard University.

Grenier, J.-C. 1983. "La stèle funéraire du dernier taureau Bouchis (Caire JE $31901=$ Stèle Bucheum 20) Ermant 4 novembre 340." Bulletin de l'Institut Français d'Archéologie Orientale du Caire 83:197-208.

Grenoble, L. A., and L. J. Whaley. 1998. "Toward a Typology of Language Endangerment." In L. A. Grenoble and L. J. Whaley, eds., Endangered Languages: Language Loss and Community Response. Cambridge: Cambridge University Press, 22-54.

Griffith, F. L1. 1935. Catalogue of the Demotic Graffiti of the Dodecaschoenus. Service des Antiquités de l'Egypte: Les Temples Immergés de la Nubie. 2 vols. Oxford: Printed at the University Press.

Grillo, R. 1989. Dominant Languages: Language and Hierarchy in Britain and France. Cambridge: Cambridge University Press.

Gustavson, H., and S.-G. Hallonquist. 1994. Dalrunorna: en vidareutveckling av de medeltida runorna? In S. Benneth, J. Ferenius, H. Gustavson, and M. Åhlén, eds., Runmärkt från brev till klotter. Stockholm: Carlssons, 157-76.

Halverson, J. 1992. "Goody and the Implosion of the Literacy Thesis." Man 27:301-17.

Harris, W. V. 1989. Ancient Literacy. Cambridge, Mass.: Harvard University Press.

Haugen, E. 1971. "The Ecology of Language.” The Linguistic Reporter 13, supplement 25:19-25.

Havelock, E. 1982. The Literate Revolution in Greece and its Cultural Consequences. Princeton: Princeton University Press.

Hawkins, J. D. 1995. "Karkamish and Karatepe: Neo-Hittite city-states in North Syria." In J. M. Sasson, J. Baines, G. M. Beckman, and K. S. Rubinsohn, eds., Civilizations of the Ancient Near East. New York: Scribners, II:1295-307.

Hill, R. M., II. 1991. "The Social Uses of Writing among the Colonial Cakchiquel Maya: Nativism, Resistance, and Innovation.” In D. H. Thomas, ed., Columbian Consequences: Volume 3. Washington, D.C.: Smithsonian Institution Press, 283-99.

Houston, S. D. 1989. Reading the Past: Maya Glyphs. London: British Museum. . 1994a. "Literacy among the Pre-Columbian Maya: A Comparative Perspective." In E. H. Boone and W. D. Mignolo, eds., Writing without Words: Alternative Literacies in Mesoamerica and the Andes. Durham: Duke University Press, 27-49. 1994b. Mesoamerican Writing. In R. E. Asher and J.M.Y. Simpson, eds., The Encyclopedia of Language and Linguistics, Volume 5. Oxford: Pergamon Press, 2449-51.

2000. "Into the Minds of Ancients: Advances in Glyph Studies." Journal of World Prehistory 14:121-201.

. 2003b (in press). "First Writing in Mesoamerica: The Maya and their Precur- 
sors.” In S. D. Houston, ed., The First Writing. Cambridge: Cambridge University Press.

Houston, S. D., O. Chinchilla Mazariegos, and D. Stuart, eds. 2001. The Decipherment of Ancient Maya Writing. Norman: University of Oklahoma Press.

Houston, S. D., ed. 2003a (in preparation). The First Writing. Cambridge: Cambridge University Press.

Houston, S. D., Robertson J., and D. Stuart. 2000. "The Language of Classic Maya Inscriptions." Current Anthropology 41, 3:321-56.

Houston, S. D., and D. Stuart. 1998. "The Ancient Maya Self: Personhood and Portraiture in the Classic Period." RES 33:73-101.

Hunger, H. 1968. Babylonische und assyrische Kolophone. Alter Orient und Altes Testament 2. Kevelaer/Neukirchen-Vluyn: Butzon \& Bercker/Neukirchener Verlag.

Hunger, H., and D. Pingree. 1999. Astral Sciences in Mesopotamia. Leiden: Brill.

Inomata, T., and L. Stiver. 1998. "Floor Assemblages from Burned Structures at Aguateca, Guatemala: A Study of Classic Maya Households." Journal of Field Archaeology 25:431-52.

Jackson, A. 1979. Na-khi Religion: An Analytical Appraisal of the Na-khi Ritual Texts. The Hague: Mouton.

Karttunen, F. 1982. "Nahuatl Literacy." In G. A. Collier, R. I. Rosaldo, and J. D. Wirth, eds., The Inca and Aztec States, 1400-1800: Anthropology and History. New York: Academic Press, 395-417.

- 1994. Between Worlds: Interpreters, Guides, and Survivors. New Brunswick: Rutgers University Press.

Kaufman, T., and J. Justeson. 2001. Epi-Olmec Hieroglyphic Writing and Texts. Workbook prepared for Texas 2001 Maya Weekend, University of Texas, Austin.

Keppie, L. 1991. Understanding Roman Inscriptions. Baltimore: Johns Hopkins University Press.

Kirch, P. V. 2000. On the Road of the Winds: An Archaeological History of the Pacific Islands Before European Contact. Berkeley: University of California Press.

Kuhrt, A., and S. Sherwin-White. 1987. Hellenism in the East. Berkeley: University of California Press.

Kurylowicz, J. 1966. "La nature des procès dits “Analogiques."” In E. P. Hamp, F. W. Householder, and R. Austerlitz, eds., Readings in Linguistics II. Chicago: University of Chicago Press, 158-74.

Larsen, M. T. 1988. "Introduction: Literacy and Social Complexity." In J. Gledhill, B. Bender, and M. T. Larsen, eds., State and Society: The Emergence and Development of Social Hierarchy and Political Centralization. London: Unwin Hyman, 173-91.

Layton, B. 2000. A Coptic Grammar, with Chrestomathy and Glossary-Sahidic Dialect. Porta Linguarum Orientalium 20. Wiesbaden: Harrassowitz.

Leclant, J., A. Heyler, C. Berger-El Naggar, C. Carrier, and C. Rilly. 2000. Répertoire d'épigraphie méroütique: corpus des inscriptions publiées. 3 vols. Paris: de Boccard.

Lévi-Strauss, C. 1955. Tristes tropiques. Paris: Librairie Plon.

Lewis, N. 1993. “The Demise of the Demotic Document: When and Why?" Journal of Egyptian Archaeology 79:276-81.

Liverani, M. 1998. Uruk, la prima città. Rome: Laterza. (English translation, by Z. Bahrani and M. Van De Mieroop, Uruk, the First City. Chicago: University of Chicago Press, in press)

Lovell, W. George. 1991. "Disease and Depopulation in Early Colonial Guatemala." In N. D. Cook and W. G. Lovell, eds., "Secret Judgments of God": Old World Disease in Colonial Spanish America. Norman: University of Oklahoma Press, 49-83.

MacGinnis, J. 1995. Letter Orders from Sippar. Poznan: Bonami. 
Marcus, J. 1992. Mesoamerican Writing Systems: Propaganda, Myth, and History in Four Ancient Civilizations. Princeton: Princeton University Press.

Martin, S., and N. Grube. 2000. Chronicle of the Maya Kings and Queens: Deciphering the Dynasties of the Ancient Maya. London: Thames and Hudson.

Mathieu, B. 1996. "Modifications de texte dans la Pyramide d'Ounas." Bulletin de l'Institut Français d'Archéologie Orientale du Caire 96:289-311.

Maul, S. 1995. "La fin de la tradition cunéiforme et les 'Graeco-Babyloniaca.'” Cahiers du Centre G. Glotz, 6:3-17.

Michalowski, P. 1994. "Writing and Literacy in Early States: A Mesopotamianist Perspective." In D. Keller-Cohen, ed., Literacy: Interdisciplinary Conversations. Cresskill, N.J.: Hampton Press, 49-70.

2000. "The Life and Death of the Sumerian Language in Comparative Perspective." Acta Sumerologica 22. http://www-personal.umich.edu/ piotrm/DIGLOS $\sim 1$. htm.

Millet, N. B. 1996. "The Meroitic Script.” In P. T. Daniels and W. Bright, eds., The World's Writing Systems. Oxford: Oxford University Press, 84-87.

Mithen, S. 1994. "From Domain Specific to Generalized Intelligence: A Cognitive Interpretation of the Middle/Upper Paleolithic Transition." In C. Renfrew and E. B. W. Zubrow, eds., The Ancient Mind: Elements of Cognitive Archaeology. Cambridge: Cambridge University Press, 29-39.

Mobbs, M. C. 1981. "Two Languages or One? The Significance of the Language Names. 'Hindi' and 'Urdu.'” Journal of Multilingual and Multicultural Development 2:203-11.

Monaghan, J. 1995. The Covenants with Earth and Rain: Exchange, Sacrifice, and Revelation in Mixtec Sociality. Norman: University of Oklahoma Press.

Monaghan, J., and B. Hamman. 1998. "Reading as Social Practice and Cultural Construction." Indiana Journal of Hispanic Literatures 13:131-40.

Moran, W. 1992. The Amarna Letters. Baltimore: The Johns Hopkins University Press.

Navarrete, C., T. A. Lee, Jr., and C. Silva R. 1993. Un catálogo de frontera: Esculturas, petroglifos y pinturas de la región media del Grijalva, Chiapas. México (DF): Universidad Nacional Autónoma de México.

Nicholson, H. B. 1973. "Phoneticism in Late Pre-Hispanic Central Mexican Writing System.” In E. P. Benson, ed., Mesoamerican Writing Systems. Washington, D.C.: Dumbarton Oaks, 1-46.

O’Connor, M. 1996. "Epigraphic Semitic Scripts.” In P. T. Daniels and W. Bright, eds., The World's Writing Systems. Oxford: Oxford University Press, 88-107.

Oelsner, J. 1978. "Kontinuität und Wandel in Gesellschaft und Kultur Babyloniens in hellenistischer Zeit." Klio 60:101-16.

- 1986. Materialien zur babylonischen Gesellschaft und Kultur in hellenistischer Zeit. Budapest: Eötvös Lorand University.

- 2002. "Sie ist gefallen, sie ist gefallen, Babylon die grosse Stadt." Vom Ende einer Kultur. Sitzungsberichte der Sächsichen Akademie der Wissenschaften, Philologisch-historische Klasse 138/1. Stuttgart and Leipzig: S. Hirzel.

Ong, W. 1982. Orality and Literacy: The Technologizing of the Word. London: Methuen.

Orlandi, T. 1991. "Literature, Coptic." In A. S. Atiya, ed., The Coptic Encyclopedia. New York and Toronto: Macmillan, 8:1450-60.

Osing, J. 1976. Der spätägyptische Papyrus BM 10808. Ägyptologische Abhandlungen 33. Wiesbaden: Otto Harrassowitz.

- 1998. Hieratische Papyri aus Tebtunis I. The Carlsberg Papyri 2; CNI Publications 17. 2 vols. Copenhagen: Museum Tusculanum Press.

Osing, J., and G. Rosati 1998. Papiri geroglifici e ieratici da Tebtynis. Florence: Istituto papirologico G. Vitelli. 
Parker, R. A. 1940. "A Late Demotic Gardening Agreement: Medinet Habu Ostracon 4038." Journal of Egyptian Archaeology 26:84-113.

Parpola, A. 1994. Deciphering the Indus Script. Cambridge: Cambridge University Press.

Pinker, S. 2001. "Talk of Genetics and Vice Versa.” Nature 413:465-66.

Pollock, S. 2001. "The Death of Sanskrit." Comparative Studies in Society and History 43:392-426.

Pope, M. 1999. The Story of Decipherment: From Egyptian Hieroglyphs to Maya Script. London: Thames and Hudson.

Postgate, N., T. Wang, and T. Wilkinson. 1995. "The Evidence for Early Ceremonial Writing: Utilitarian or Ceremonial?" Antiquity 69:459-80.

Potter, D. S. 1990. Prophecy and History in the Crisis of the Roman Empire: A Historical Commentary on the Thirteenth Sibylline Oracle. Oxford Classical Monographs. Oxford: Clarendon Press.

Prem, H. J. 1999. "The Canek Manuscript and Other Faked Documents." Ancient Mesoamerica 10, 2:297-311.

Quaegebeur, J. 1991. "Pre-Coptic" and "Pre-Old Coptic." In A. S. Atiya, ed., The Coptic Encyclopedia. New York and Toronto: Macmillan, VIII:188-91.

Raven, M. J. 1991. The Tomb of Iurudef, a Memphite Official in the Reign of Ramesses II. Egypt Exploration Society, Excavation Memoir 57. Leiden and London: National Museum of Antiquities Leiden; Egypt Exploration Society.

Ray, J. D. 1994. "How Demotic Is Demotic?" Egitto e Vicino Oriente 17:251-64.

Reisner, G. 1896. Sumerisch-babylonische Hymnen nach Thontafeln griechischer Zeit. Berlin: W. Spemann.

Rempel, J., and N. Yoffee 1999. "The End of the Cycle? Assessing the Impact of Hellenization on Mesopotamian Civilization.” In B. Böck, E. C. Cancik-Kirschbaum, and T. Richter, eds., Minuscula Mesopotamica: Festschrift für Johannes Renger. Alter Orient und Altes Testament 267. Münster: Ugarit-Verlag, 384-98.

Restall, M. 1997. "Heirs to the Hieroglyphs: Indigenous Writing in Colonial Mesoamerica." The Americas 54:239-67.

Riggs, C. 2002. "Facing the Dead: Recent Research on the Funerary Art of Ptolemaic and Roman Egypt." American Journal of Archaeology 106:85-101.

- 2003. "The Egyptian Funerary Tradition at Thebes in the Roman Period." In N. Strudwick and J. H. Taylor, eds., The Theban Necropolis: Past, Present and Future (International Colloquium, 27-28 July 2000). London: British Museum Press, (pp. n.a.).

Ritner, R. K. 1996. "Egyptian Writing.” In P. T. Daniels and W. Bright, eds., The World's Writing Systems. Oxford: Oxford University Press, 73-84.

Robertson, J. n.d. "The Breadth and Depth of Markedness." http://humanities.byu.edu/ Linguistics/ling535/peirce/markedness_1.html

Robinson, A. 2001. Lost Languages: The Riddle of the World's Undeciphered Scripts. New York: McGraw-Hill.

Sachs, A. 1976. "The Latest Datable Cuneiform Tablets." In B. Eichler, J. W. Heimerdinger, and Å. Sjöberg, eds., Kramer Anniversary Volume. Alter Orient und Altes Testament 25. Kevelaer/Neukirchen-Vluyn: Butzon \& Bercker/Neukirchner Verlag, 379-98.

Salvesen, A. 1998. "The Legacy of Babylon and Nineveh in Aramaic Sources." In S. Dalley, ed., The Legacy of Mesopotamia. Oxford: Oxford University Press, 139-61.

Sampson, G. 1985. Writing Systems: A Linguistic Introduction. Stanford: Stanford University Press.

Sasse, H.-J. 1992. “Theory of Language Death.” In M. Brenzinger, ed., Language 
Death: Factual and Theoretical Explorations with Special Reference to East Africa. Berlin: Mouton de Gruyter, 7-30.

Satzinger, H. 1991. "Old Coptic." In A. S. Atiya, ed., The Coptic Encyclopedia. New York and Toronto: Macmillan, VIII:169-75.

Sauneron, S. 1975. Le temple d'Esna, nos. 473-546. Esna VI: 1. Cairo: Institut Français d'Archéologie Orientale.

1982. L'écriture figurative dans les textes d'Esna. Esna VIII. Cairo: Institut Français d'Archéologie Orientale.

Scharff, A. 1927. "Ein Denkstein der römischen Kaiserzeit aus Achmim." Zeitschrift für Ägyptische Sprache und Altertumskunde 62:86-107.

Schmidt, P., M. de la Garza, and E. Nalda, eds. 1998. Maya. New York: Rizzoli.

Schmitt, A. 1963. Die Bamum-Schrift. Wiesbaden: Otto Harrassowitz.

Sherwin-White, S. 1987. "Seleucid Babylonia: A Case Study for the Installation and Development of Greek Rule." In A. Kuhrt and S. Sherwin-White, eds., Hellenism in the East. Berkeley: University of California Press, 32-56.

Sims-Williams, P. 1993. "Some Problems in Deciphering the Early Irish Ogam Alphabet." Transactions of the Philological Society 91: 133-80.

Smith, H. S., and W. J. Tait 1984. Saqqara Demotic Papyri I. Texts from Excavations 7. London: Egypt Exploration Society.

Smith, R. E. 1975. The Pottery of Mayapan. Papers of the Peabody Museum of Archaeology and Ethnology, vol. 66. Cambridge, Mass.: Harvard University.

Salomon, R. 1998. Indian Epigraphy: A Guide to the Study of Inscriptions in Sanskrit, Prakrit, and the Other Indo-Aryan Languages. Oxford: Oxford University Press.

Spek, R. van der. 1987. "The Babylonian City." In A. Kuhrt and S. Sherwin-White, eds., Hellenism in the East. Berkeley: University of California Press, 57-74.

- 1998. "Cuneiform Documents on Parthian History: The Rahimesu Archive." In J. Wiesehöfer, ed., Das Partherreich und seine Zeugnisse. Historia Einzelschriften 122. Stuttgart: F. Steiner, 205-58.

Sternberg-el Hotabi, H. 1994. "Der Untergang der Hieroglyphenschrift: Schriftverfall und Schrifttod im Ägypten der griechisch-römischen Zeit." Chronique d'Egypte 69: $218-48$.

. 1999. Untersuchungen zur Überlieferungsgeschichte der Horusstelen: Ein Beitrag zur Religionsgeschichte Ägyptens im 1. Jahrtausend v. Chr. Ägyptologische Abhandlungen 62.2 vols. Wiesbaden: Harrassowitz.

Stone, A. 1995. Images from the Underworld: Naj Tunich and the Tradition of Maya Cave Painting. Austin: University of Texas Press.

Streck, M. 1995. Zahl und Zeit. Grammatik der Numeralia und des Verbalsystems im spätbabylonischen. Groningen: Styx.

— 2001. "Keilschrift und Alphabet." In D. Borchers et al., eds., Hieroglyphen, Alphabete, Schriftreformen. Lingua Aegyptia, Studia Monographica 3. Göttingen: Seminar für Ägyptologie und Koptologie, 77-97.

Strecker, M., and J. Artieda. 1978. "La relación de algunas costumbres (1582) de Gaspar Antonio Chi." Estudios de Historia Novohispana 6:89-107.

Street, B. V. 1993. "Introduction: the new literacy studies." In B. Street, ed., Crosscultural Approaches to Literacy. Cambridge: Cambridge University Press, 1-21.

Sturm, C. 1996. "Old Writing and New Messages: The Role of Hieroglyphic Literacy in Maya Cultural activism." In E. F. Fischer and R. McK. Brown, eds., Mayan Cultural Activism in Guatemala. Austin: University of Texas Press, 114-30.

Tadmor, H. 1991. "On the Role of Aramaic in the Assyrian Empire." In M. Mori, H. Ogawa, and M. Yoshikawa, eds., Near Eastern Studies Dedicated to H.I.H. Takahito Mikasa. Wiesbaden: Harrassowitz, 419-26. 
Tainter, J. A. 1988. The Collapse of Complex Societies. Cambridge: Cambridge University Press.

Tardits, C. 1980. Le royaume Bamoum. Paris: Armand Colin.

Tait, J. 1994. "Some Notes on Demotic Scribal Training in the Roman Period." In A. Bülow-Jacobsen, ed., Proceedings of the 20th International Congress of Papyrologists, Copenhagen, 23-29 August, 1992. Copenhagen: Museum Tusculanum Press, $188-92$.

-2001. "Exuberance and Accessibility: Notes on Written Demotic and the Egyptian Scribal Tradition." In T. Gagos and R. S. Bagnall, eds., Essays and Texts in Honor of J. David Thomas. American Studies in Papyrology 42. Ann Arbor, Mich.: American Society of Papyrologists, 31-39.

Taube, K. A. 1988. “A Prehispanic Maya Katun Wheel.” Journal of Anthropological Research 44, 2: 183-203.

1989. Itzam Cab Ain: Caimans, Cosmology, and Calendrics in Postclassic Yucatán. Research Reports on Ancient Maya Writing 26. Washington, D.C.: Center for Maya Research.

- 2000. The Writing System of Ancient Teotihuacan. Ancient America 1. Washington D.C.: Center for Ancient American Studies.

Taube, K. A., and B. L. Bade. 1991. An Appearance of Xiuhtecuhtli in the Dresden Venus Pages. Research Reports on Ancient Maya Writing 35. Washington, D.C.: Center for Maya Research.

Traunecker, C. 1991. "Observations sur le décor des temples égyptiens.” In F. Dunand, J.-M. Spieser, and J. Wirth, eds., L'image et la production du sacré. Paris: Méridiens Klincksieck, 77-101.

Trigger, B. G. 1998. "Writing Systems: A Case Study in Cultural Evolution." Norwegian Archaeological Review 31, 1:39-62.

Turvey, M. T., L. B. Feldman, and G. Lukatela. 1984. "The Serbo-Croatian Orthography Constrains the Reader to a Phonologically Analytic Strategy." In L. Henderson, ed., Orthographies and Reading. London: Erlbaum, 81-89.

Underhill, R. 1976. Turkish Grammar. Cambridge, Mass.: MIT Press.

Verhoeven, U. 1999. "Von hieratischen Literaturwerken in der Spätzeit." In J. Assmann and E. Blumenthal, eds., Literatur und Politik im pharaonischen und ptolemäischen Ägypten: Vorträge der Tagung zum Gedenken an Georges Posener 5.-10. September 1996 in Leipzig. Bibliothèque d'Etude 127. Cairo: Institut Français d'Archéologie Orientale, 255-65.

Vittmann, G. 1998. Der demotische Papyrus Rylands 9. Ägypten und Altes Testament 38, 2 vols. Wiesbaden: Harrassowitz.

Vleeming, S. P. 1981. "La phase initiale du démotique ancien." Chronique d'Egypte $56: 31-48$.

_ 1994 "Some Notes on Demotic Scribal Training in the Ptolemaic Period." In A. Bülow-Jacobsen, ed., Proceedings of the 20th International Congress of Papyrologists, Copenhagen, 23-29 August, 1992. Copenhagen: Museum Tusculanum Press, $185-87$.

Vleeming, S. P., and J. W. Wesselius 1985. Studies in Papyrus Amherst 63: Essays on the Aramaic Texts in Aramaic/Demotic Papyrus Amherst 63 I. Amsterdam: Juda Palache Instituut.

Volk, K. 1999. "Imkerei im alten Mesopotamien." In H. Klengel and J. Renger, eds., Landwirtschaft im Alten Orient. Proceedings of the 41st Rencontre Assyriologique Internationale. Berlin: D. Reimer, 279-90.

Watt, R. G. 1994. “The Deseret Alphabet.” In A. K. Powell, ed., Utah History Encyclopedia. Salt Lake City: University of Utah Press, 139-40. 
Webster, D. 2002. The Fall of the Ancient Maya: Solving the Mystery of the Maya Collapse. London: Thames and Hudson.

Wiesehöfer, J. 2001. Ancient Persia. London: I. B. Tauris.

Widmer, G. In press. "Une invocation à la déesse (Tablette démotique Louvre E 10382)." In F. Hoffmann and H.-J. Thissen, eds., Festschrift volume [title n.a.]. Würzburg.

Wilfong, T. G. 2002. Women of Jeme: Life in a Coptic Town in Late Antique Egypt. Ann Arbor, Mich.: University of Michigan Press.

Williams, H. 2001. "The Romans and the Runes: Uses of Writing in Germania.” In S. Nyström, ed., Runor och AB.C.: Elva föreläsningar från ett symposium I Stockholm våren 1995. Stockholm: Stockholms Medeltidsmuseum, 177-92.

Winter, E. 1980. "Philae." In W. Helck and W. Westendorf, eds., Lexikon der Ägyptologie. Wiesbaden: Otto Harrassowitz, IV: 1022-27.

Wolf, E. R. 1955. "Types of Latin American Peasantry: A Preliminary Discussion." American Anthropologist 57:452-71.

. 1987. "The Vicissitudes of the Closed Corporate Peasant Community." American Ethnologist 13:325-29.

Yadeun, J. 1993. Toniná. Mexico: El Equilibrista.

Yoffee, N., and G. L. Cowgill, eds. 1988. The Collapse of Ancient States and Civilizations. Tucson: University of Arizona Press. 